\title{
Can Selenium and Molybdenum Restrain Cadmium Toxicity to Pollen Grains in Brassica napus?
}

\author{
Marwa A. Ismael 1,2,3 (1D, Ali Mohamed Elyamine 1,2, Yuan Yuan Zhao 1,2, \\ Mohamed G. Moussa 1,2,4 (iD), Muhammad Shoaib Rana 1,2 , Javaria Afzal 1,2 (D), \\ Muhammad Imran ${ }^{1,2}$, Xiao Hu Zhao ${ }^{1,2}$ and Cheng Xiao $\mathrm{Hu}{ }^{1,2, *}$ \\ 1 Key Laboratory of Arable Land Conservation (Middle and Lower Reaches of Yangtze River), Ministry of \\ Agriculture, Huazhong Agricultural University, Wuhan 430070, China; maf02@fayoum.edu.eg (M.A.I.); \\ elyoh@hotmail.fr (A.M.E.); yuanyuanzhao666@gmail.com (Y.Y.Z.); \\ MohamedGomaa_Ali@agr.asu.edu.eg (M.G.M.); muhammadshoaib@webmail.hzau.edu.cn (M.S.R.); \\ juvaria_afzal@outlook.com (J.A.); imrangorayauaf@yahoo.com (M.I.); xhzhaowhu@163.com (X.H.Z.) \\ 2 Hubei Provincial Engineering Laboratory for New-Type Fertilizers, Huazhong Agricultural University, \\ Wuhan 430070, China \\ 3 Botany Department, Faculty of Science, Fayoum University, Fayoum 63514, Egypt \\ 4 Soil and Water Research Department, Nuclear Research Center, Egyptian Atomic Energy Authority, \\ Abou Zaabl 13759, Egypt \\ * Correspondence: hucx@mail.hzau.edu.cn
}

Received: 2 July 2018; Accepted: 19 July 2018; Published: 24 July 2018

\begin{abstract}
Cadmium (Cd) is highly toxic, even at very low concentrations, to both animals and plants. Pollen is extremely sensitive to heavy metal pollutants; however, less attention has been paid to the protection of this vital part under heavy metal stress. A pot experiment was designed to investigate the effect of foliar application of Se $(1 \mathrm{mg} / \mathrm{L})$ and Mo $(0.3 \mathrm{mg} / \mathrm{L})$ either alone or in combination on their absorption, translocation, and their impact on $\mathrm{Cd}$ uptake and its further distribution in Brassica napus, as well as the impact of these fertilizers on the pollen grains morphology, viability, and germination rate in B. napus under Cd stress. Foliar application of either Se or Mo could counteract $\mathrm{Cd}$ toxicity and increase the plant biomass, while combined application of Se and Mo solutions on B. napus has no significant promotional effect on plant root and stem, but reduces the seeds' weight by 10-11\%. Se and Mo have decreased the accumulated Cd in seeds by $6.8 \%$ and $9.7 \%$, respectively. Microscopic studies, SEM, and pollen viability tests demonstrated that pollen grains could be negatively affected by $\mathrm{Cd}$, thus disturbing the plant fertility. Se and Mo foliar application could reduce the toxic symptoms in pollen grains when the one or the other was sprayed alone on plants. In an in vitro pollen germination test, $500 \mu \mathrm{M} \mathrm{Cd}$ stress could strongly inhibit the pollen germination rate to less than $2.5 \%$, however, when Se $(10 \mu \mathrm{M})$ or Mo $(1.0 \mu \mathrm{M})$ was added to the germination medium, the rate increased, reaching $66.2 \%$ and $39.4 \%$, respectively. At the molecular level, Se and Mo could greatly affect the expression levels of some genes related to Cd uptake by roots (IRT1), Cd transport (HMA2 and HMA4), Cd sequestration in plant vacuoles (HMA3), and the final Cd distribution in plant tissue at the physiological level (PCS1).
\end{abstract}

Keywords: oilseed rape (Brassica napus); foliar fertilizers; heavy metal stress; molybdenum; selenium; pollen grains; metal transporters

\section{Introduction}

Cadmium (Cd) as one of the most toxic metals to both vertebrates and vascular plants is widespread in soil, water, and the atmosphere due to industrial emissions, sewage sludge, as well as 
phosphate fertilizers applications, and public waste disposal containing $\mathrm{Cd}[1,2]$. Its presence in soil, water, and even the atmosphere can cause serious problems to all organisms, and its bioaccumulation in the food chain can be highly dangerous [3]. Although Cd is not essential for plant growth, it is readily absorbed by the plants and translocated to the edible parts where it is accumulated at high levels. Cd interferes with many cellular functions leading to retardation of plant growth, leaf chlorosis and a decrease in photosynthesis rate, diminishing water and nutrient uptake, which might ultimately result in the plant death [4]. In addition, it can cause oxidative stress and alter the functionality of membranes and the nitrogen metabolism [5].

Brassica napus is widely planted as a Cd-hyperaccumulator [6]. In B. napus, Cd is reported to cause suppressed growth, decrease in the photosynthetic pigments content, as well as the activities of antioxidant enzymes, and increases in malondialdehyde and reactive oxygen species (ROS). In addition, it severely damages the leaf and root tip cell [7]. Due to its high mobility, Cd can be transferred to the reproductive tissues of the plant, such as flowers and pollens to affect their development and impair seed formation. Based on literature survey, $\mathrm{Cd}^{2+}, \mathrm{Cu}^{2+}$, and $\mathrm{Hg}^{2+}$ showed the highest toxicity towards the in vitro pollen germination and pollen tube growth in Lilium longiflorum [8]. In addition, $\mathrm{Cd}^{2+}$ was the only one out of the screened metals which was found to cause intracellular interactions and affect the organelles distribution within the pollen tip regions $[9,10]$. Several studies indicated that cadmium strongly inhibits in vitro pollen germination and pollen tube growth [11-13]. Cd also negatively affects plant reproduction by inhibiting pollen germination and ovule growth and, therefore, induces invalid flowers and shriveled grains [14].

Selenium (Se) is considered an essential nutrient for humans and animals [15,16], however, not for some other organisms, including plants. At low dosages, Se exerts diverse beneficial effects on different plant physiological processes leading to enhanced plant growth and high yields [17]. The use of selenium in the form of foliar spray or base fertilizer is well documented to increase its content in the edible parts of the plants. It can also mitigate the negative effects caused by variety of environmental stresses [18]. Se has been used to protect plants subjected to Cd [19], though the mechanism of its action is not completely clear, however, the regulation of ROS, antioxidants, Cd-uptake, and its further translocation, Cd-storage in non/less-toxic forms, as well as the recovery of the photosynthetic system and reconstruction of cell membranes and chloroplasts, has been proved to be involved in the protection process [18].

Molybdenum (Mo) is one of the micronutrients required by plants as well as animals in very small amounts for normal growth. It is principally used in the production of "molybdo-enzymes" that control various plant functions. In plants, Mo deficiency negatively affects some plant activities such as photosynthesis, root growth, and some nitro-enzymes [20,21]. In addition, it affects flowering and pollen production capacity, the grain size and pollen germination, thus, the quality and production of crops are negatively affected [22]. Foliar applications of Mo are proved to be a very beneficial source of Mo, even more effective than soil applications, particularly for acidic soils [23], or under dry conditions [24]. Application of Mo could increase growth, photosynthesis, chlorophyll, and the antioxidative capacity of plants [25]. Molybdenum application enhances the salinity stress tolerance in Brassica campestris by increasing its capacity to eliminate active oxygen [26]. The potential of Mo to alleviate the acute toxicity of Cd in animals has been recognized a long time ago [27]. However, just recently, molybdenum has been reported to increase the phytoremediation ability of Ricinus communis L. for Cd removal and to alleviate Cd-toxic symptoms under Cd stress [28].

Heavy metals uptake and transport in plants are controlled by several types of metal transporters [29]. Cd uptake by plant root cells can happen via both passive and active transport. The active uptake of $\mathrm{Cd}$ by the plant roots is mediated by ZRT (zinc-regulated transporter) and IRT (iron-regulated transporter) [30,31]. In Arabidopsis thaliana, AtIRT1 is a primary transporter for iron uptake and it also mediates $\mathrm{Cd}$ uptake by the plant roots [30]. Cd loads from symplasm into the xylem by heavy metal $\mathrm{P}_{1 \mathrm{~B}}$-ATPases, such as HMA2 and HMA4 [32]. In addition, HMA3 participate in heavy metal ion transport and detoxification and it is mainly involved in the vacuolar storage of $\mathrm{Cd}$ [33]. 
It also plays a role in $\mathrm{Cd}$ sequestration into root or leaves vacuoles, thus controlling $\mathrm{Cd}$ reaching plant seeds and enhancing the plant tolerance to Cd [34]. Phytochelatins (PCs) are small cysteine-rich peptides, that are synthesized in plants using glutathione as a substrate in a catalyzed process mediated by phytochelatin synthase PCS. Cd exposure also induces the expression of phytochelatin synthase and, thus, increases the level of phytochelatins which can make a complex with Cd (PCs-Cd complex) then it is sequestered into vacuoles for Cd detoxification [35]. Thus, overexpression of PCS, especially PCS1 was shown to confer $\mathrm{Cd}$ tolerance and control $\mathrm{Cd}$ accumulation in seeds.

In most plants, fruit formation and seed-set necessitate effective pollination, and the understanding of pollen biology, including pollen viability and pollen tube growth is required to raise the plant productivity. In many plants, the reproductive tissues are more sensitive to Mo and Se deficiency than vegetative tissues, and such deficiency may affect pollen fertility. In spite of the well documented protective role of Se and Mo, there is no available data about the possible extension of this role to the reproductive organs, either in vivo or in vitro. In addition, Mo and Se deficiency are very popular in arable land of South China, particularly in the area where B. napus grows. Thus the objectives of this present study are to (i) evaluate the effect of foliar application of Mo and Se, either alone or in combination, on Cd uptake and translocation in B. napus which is the third-largest source of vegetable oil in the world, and it is also used as a vegetable [36], (ii) investigate whether Mo and Se can restrain transferring of $\mathrm{Cd}$ to reproductive parts such as pollens and seeds, (iii) explore the effect of applying Se and Mo on pollen morphology and viability in Cd-stressed B. napus, and (iv) finally to study the protective role of Se and Mo at the molecular level via studying some metal transporters that might play a role in Cd-uptake and translocation.

\section{Results}

\subsection{Plant Biomass}

The variation in dry mass of root, stem, glume, and seed of Brassica napus under Cd stress is presented in Figure 1. Under normal conditions, without Cd stress, foliar spray of Se and Mo as fertilizers improved root, stem, glume, and seed total biomasses compared to the control. However combined Se and Mo significantly reduced the overall plant biomass. $\mathrm{Cd}$ application has negatively affected plant growth and reduced root, stem, glume, and seed dry weights by $6.52 \%, 1.65 \%, 8.45 \%$, and $10.23 \%$ respectively, compared to the control. Under Cd stress, foliar application of Mo alleviated the $\mathrm{Cd}$ toxicity and considerably increased the plant biomass by $29.56 \%, 17.79 \%, 9.41 \%$, and $15.15 \%$ for root, stem, glume, and seeds, respectively, compared to Cd application alone. Although Se foliar application enhanced plant growth and increased plant dry weight, compared to Mo application, Se effect was lower. Combined application of Se and Mo under Cd stress has no significant promotional effect on plant root and stem, however, significantly decreased glume and seed dry mass. These results suggest that Se and Mo separately enhance plant growth and could alleviate the toxic effect of Cd.

\subsection{Cd Concentration and Accumulation}

The impact of selenium and molybdenum on cadmium uptake and its distribution within oilseed rape plant was investigated. The total concentrations of cadmium, selenium, and molybdenum were determined in roots, stems, and fruits of oilseed rape and are presented in Figure 2. In one hand, Cd concentrations in roots decreased with Mo treatment by $19.35 \%$ (Figure 2A), by the same way that of stem was reduced by $5.71 \%$ (Figure 2B), suggesting that Mo inhibited Cd accumulation in roots and consequently reduced heavy metal toxic effects in stems. However, when $\mathrm{Cd}$ was supplied simultaneously with Se, its accumulation in roots was even more pronounced than when supplied separately and consequently increase heavy metals accumulation in roots and stems by $28.43 \%$ and $27.92 \%$, compared with the control (Figure 2B). These results suggest that Se enhance the plant's tolerance against $\mathrm{Cd}$ and leads to a considerable increase of $\mathrm{Cd}$ on the edible part of the plants. 
Surprisingly, applying both Se and Mo together has no significant effect in Cd root concentration, however, in stems it is slightly increased compared to control.

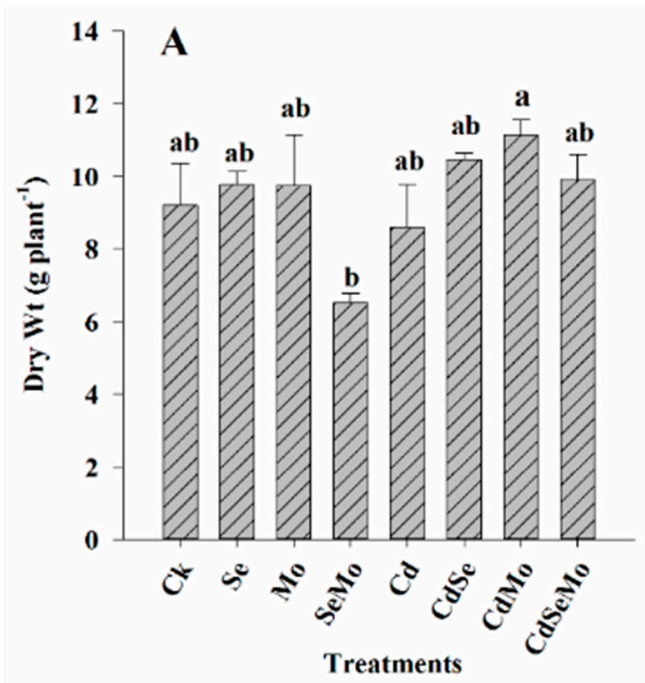

B
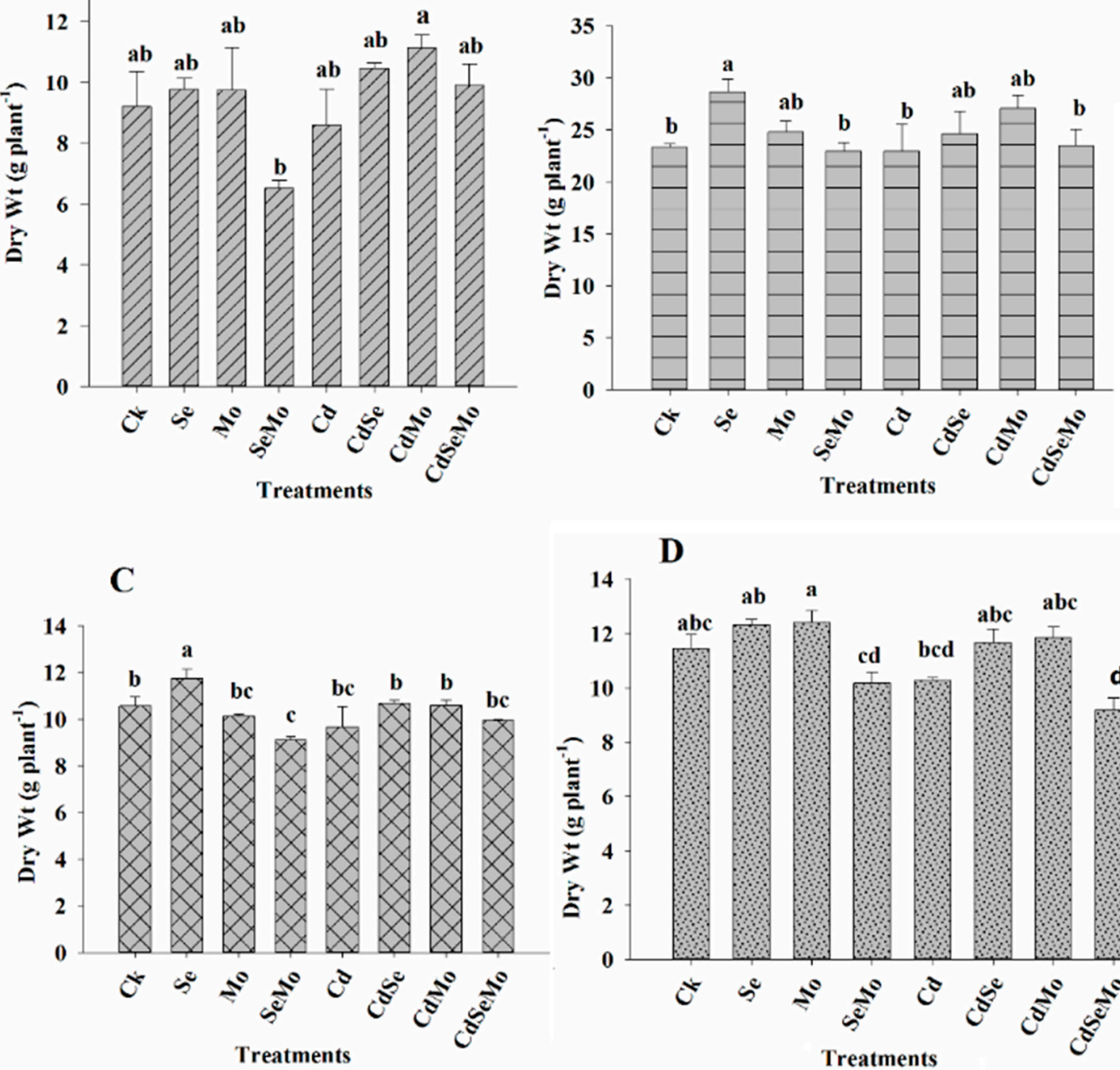

D

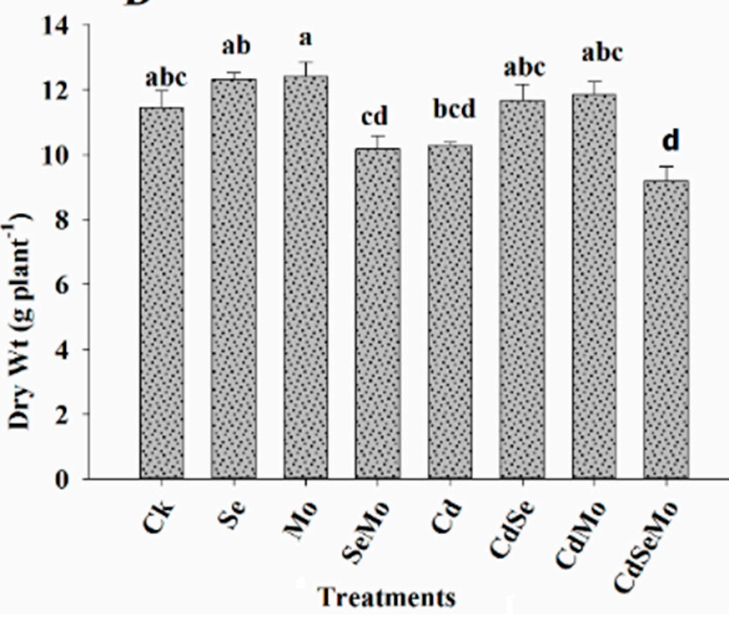

Figure 1. Dry biomasses of B. napus grown under different experimental conditions. Dry weight of root (A), stem (B), glume (C), and seed (D) of oilseed rape treated with foliar spray of $(1 \mathrm{mg} / \mathrm{L})$ Se and/or $(0.3 \mathrm{mg} / \mathrm{L}) \mathrm{Mo}$ in absence or presence of Cd stress $(5 \mathrm{mg} / \mathrm{kg})$. All data show the means \pm SD of four replicates. Different letters within a column indicate significant $(p<0.05)$ differences between treatments.

In the other hand, the trend of $\mathrm{Cd}$ accumulation in glume and seeds was slightly different from that of root and stem. In glume, separate Mo and Se foliar fertilization has significantly decreased Cd concentration by $24.9 \%$ and $43.5 \%$, respectively, compared to that of Cd treatment alone (Figure $2 \mathrm{C}$ ). In seeds, the differences of $\mathrm{Cd}$ concentrations between all the treatments are not as high as in glume, however, $\mathrm{Cd}$ concentration decreased with spraying Mo or Se separately and increased when Mo and Se were used together (Figure 2D). Considering the total $\mathrm{Cd}$ accumulated in the fruits (glume and seeds together), the sequence of $\mathrm{Cd}$ concentration follows the trend; $\mathrm{Cd}>\mathrm{Cd}+\mathrm{Mo}+\mathrm{Se}>\mathrm{Cd}+\mathrm{Mo}$ $>\mathrm{Cd}+$ Se with 13.83, 12.13, 11.09, $10.07 \mathrm{mg} \mathrm{Cd} / \mathrm{kg}$ DW, respectively. This result highlights that Se or Mo spray significantly decreases the total $\mathrm{Cd}$ reaching the plant fruit, though the amount of $\mathrm{Cd}$ accumulated in seeds is higher in the case of Se as compared to Mo. 

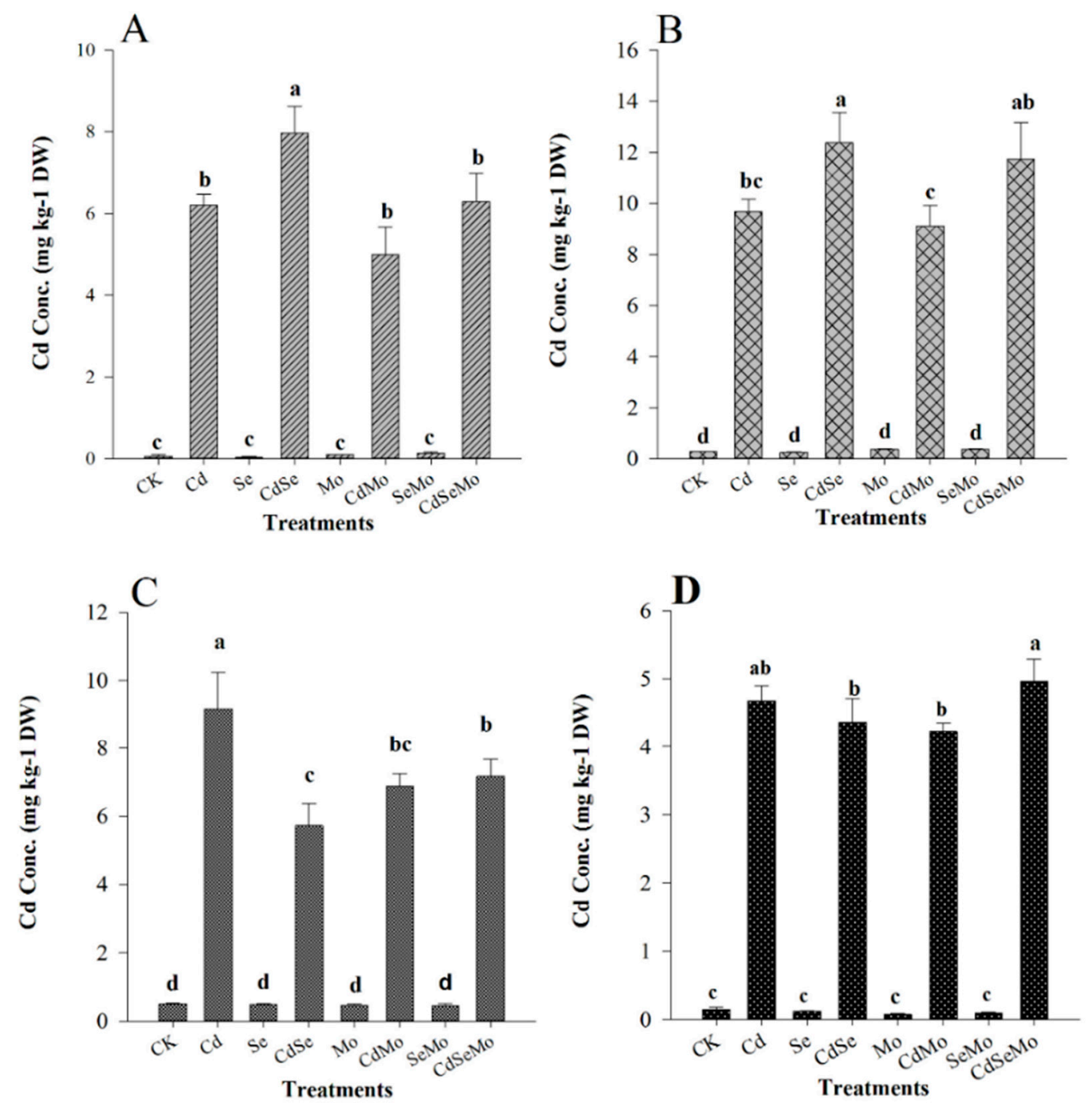

Figure 2. Concentrations of $\mathrm{Cd}$ in B. napus tissues. Cd concentration in root (A), stem (B), glume (C), and seed (D) of oilseed rape treated with foliar spray of $(1 \mathrm{mg} / \mathrm{L})$ Se and /or $(0.3 \mathrm{mg} / \mathrm{L})$ Mo in absence or presence of Cd stress $(5 \mathrm{mg} / \mathrm{kg})$. All data show the means $\pm \mathrm{SD}$ of four replicates. Different letters within a column indicate significant $(p<0.05)$ differences between treatments.

\subsection{Se and Mo Contents in Oilseed Rape}

Se and Mo concentrations in overall plant tissues are presented in Figures 3 and 4. Se, in all plant parts was significantly increased when it was applied as foliar spray following the order: Stem > glume $>$ root $>$ seed with $154.49 \%, 119.52 \%, 42.42 \%$, and $37.92 \%$, respectively, as compared to control. However, Se was not effectively translocated from shoots to roots, since a relatively lower increase of Se concentration (42.42\%) was observed in roots as compared to stems $(154.49 \%)$. Nevertheless, co-application of Mo (i.e., in Mo + Se treatments) enhances Se transport from shoot to root which was increased by $20.24 \%$ in root and decreased by $9.17 \%$ in shoot. In addition, foliar spray of Mo significantly increases Se content in seeds. In those treatments where Mo was applied as a foliar spray, its content significantly increased in the overall plant. However, in other treatments $(\mathrm{CK}, \mathrm{Cd}, \mathrm{Se}$, $\mathrm{Cd}+\mathrm{Se}$ ), no difference in Mo concentration in all plant parts was denoted, except in $\mathrm{Cd}+\mathrm{Se}$ where Mo content was significantly decreased in seeds. 

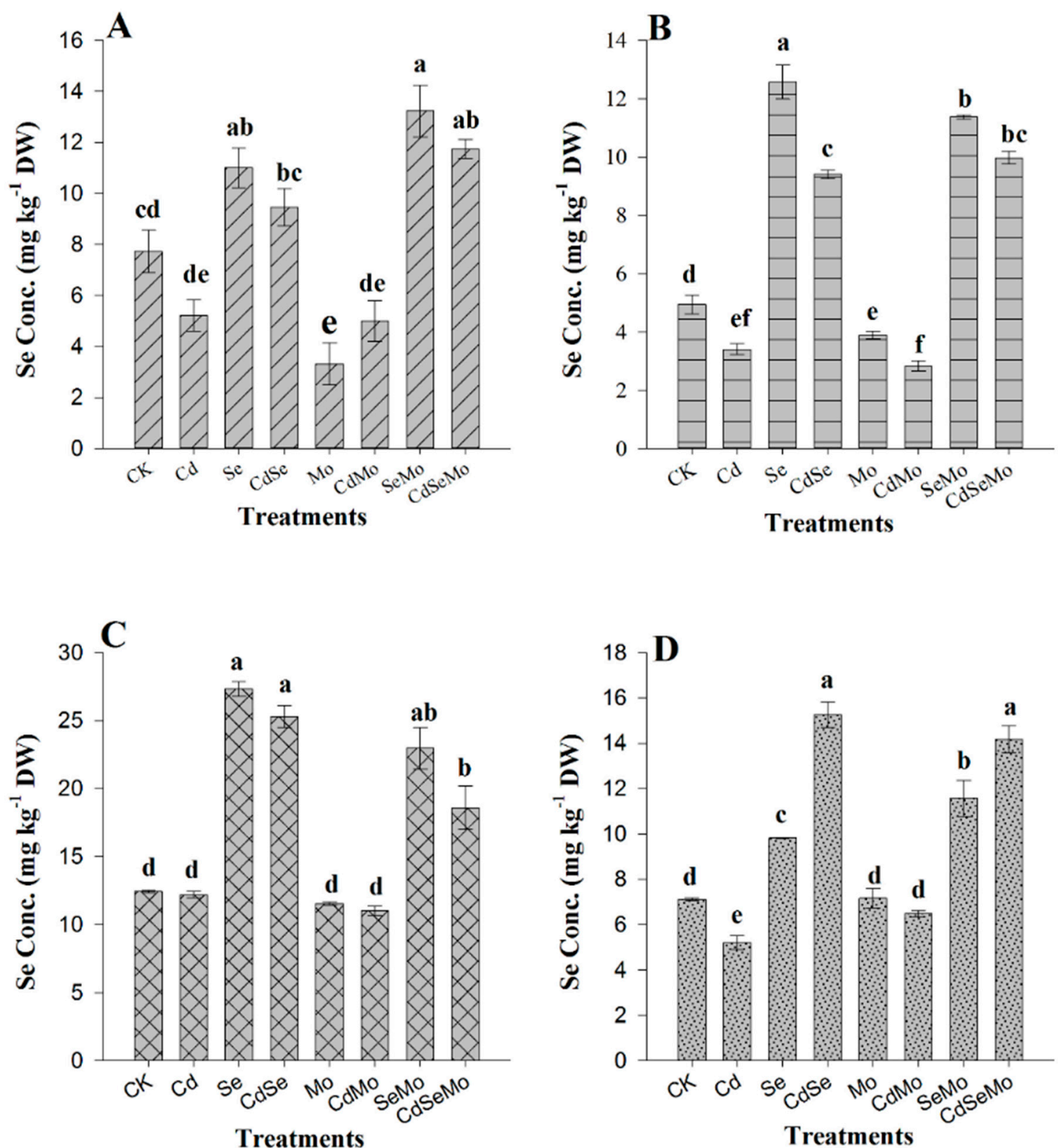

Figure 3. Concentrations of Se in B. napus tissues under different treatment conditions. Se content in root (A), stem (B), glume (C), and seed (D) of oilseed rape treated with foliar spray of $(1 \mathrm{mg} / \mathrm{L})$ Se and/or $(0.3 \mathrm{mg} / \mathrm{L}) \mathrm{Mo}$ in absence or presence of Cd stress $(5 \mathrm{mg} / \mathrm{kg})$. All data show the means $\pm \mathrm{SD}$ of four replicates. Different letters within a column indicate significant $(p<0.05)$ differences between treatments.

Soil Cd has an impact on Se accumulation since it decreases Se concentration in stems, roots, and glumes by $25.21 \%, 13.98 \%$, and $7.4 \%$, respectively, compared to Se alone. In addition, it resulted in a substantial increase in Se content of seed by 55.29\% as compared to Se only. When Mo was sprayed with Se, under cadmium stress, Se concentration in both root and seed was not affected compared with the plants supplemented with Se alone, however, it significantly decreased in stems, and glumes. Interestingly, Cd stress considerably increased the plant Mo uptake on foliar spraying, thus increasing Mo content in roots, stems, and seeds compared with those treatments supplemented with Mo alone (Figure 4). Se also affected the plant Mo uptake, since in the Se + Mo treatment, the accumulation of Mo in stems, glumes, and seeds was significantly decreased, but the root Mo content slightly 
increased. These results suggest that Se decreases Mo translocation rate from shoots to roots, however, in Cd-polluted soil, Mo concentration increased in roots whether Se was applied or not.
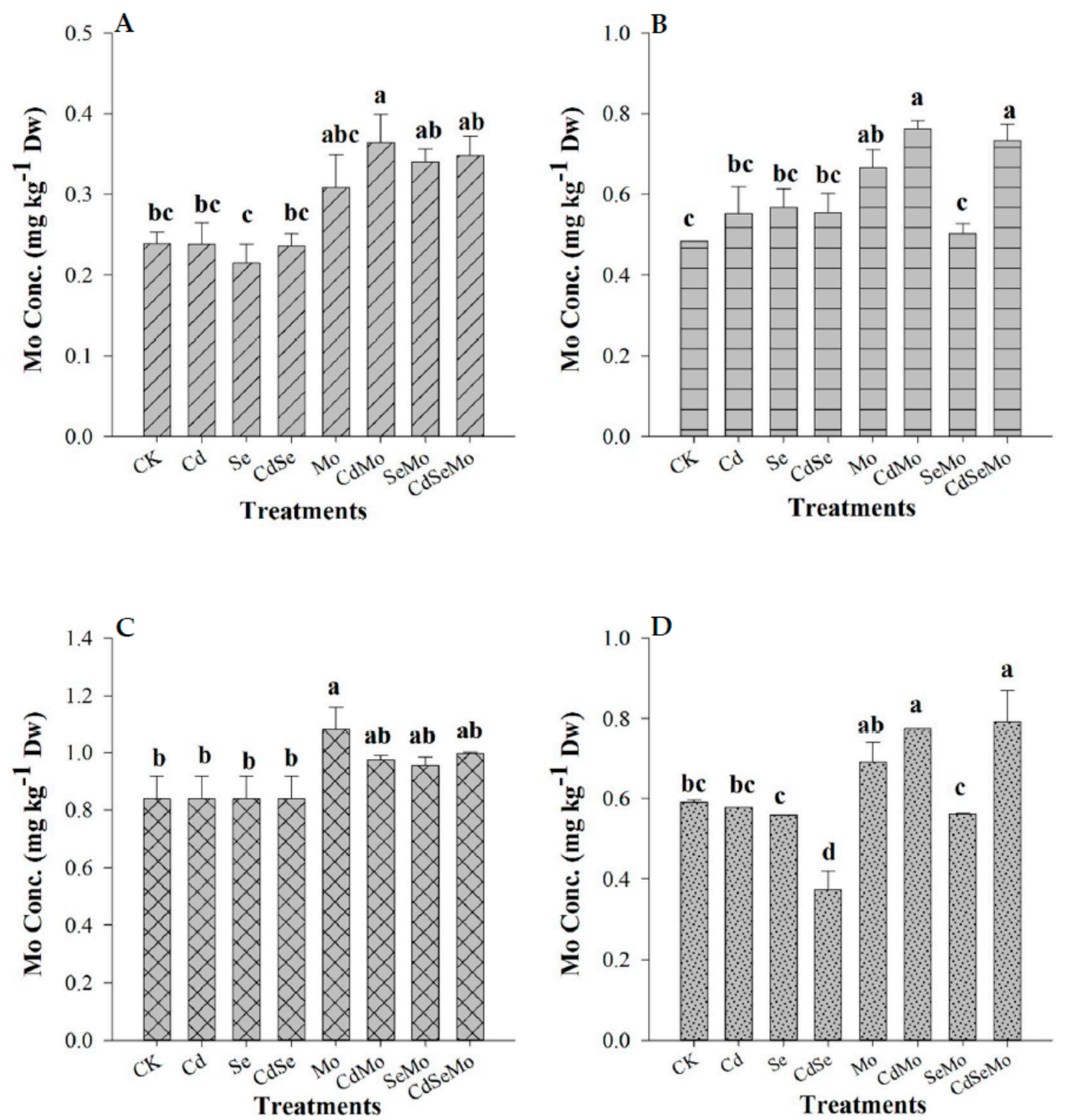

Figure 4. Concentrations of Mo in B. napus tissues under different treatment conditions. Mo content in root (A), stem (B), glume (C), and seed (D) of oilseed rape treated with foliar spray of (1 mg/L) Se and/or $(0.3 \mathrm{mg} / \mathrm{L})$ Mo in absence or presence of Cd stress $(5 \mathrm{mg} / \mathrm{kg})$. Bars indicate standard error $(n=4)$. Different letters indicate significant differences at $(p<0.05)$.

\subsection{Anther and Pollen Grains Morphology}

\subsubsection{Microscopic Studies}

Pollen structure was determined for samples grown in polluted soil under all the experimental conditions in our study and compared to the control, as presented in Figure 5. In normal plants, collected from control (CK), the anther basically consisted of four pollen sacs which occupied the bulk of each anther. Under Cd stress, plants displayed clear morphological anomalies during this stage. Pollen sacs suffered the formation of irregularly shaped microsporocytes (Figure 5C,D) and the number of pollen grains per pollen sac were significantly decreased compared to the control. In some cases, 
anther growth was even incomplete and became smaller than the control probably due to high stability of the anther wall as a defense mechanism to minimize $\mathrm{Cd}$ reaching the pollen grains. In other cases, $\mathrm{Cd}$ rendered mature anthers sterile; their exines became completely crushed and they are symbolized by a dense mass in each locule of the anther at flower anthesis (Figure 5E,F). Based on these results, it can be concluded that the anther development in Brassica napus was seriously affected by Cd. Yet, when Se or Mo was applied individually in Cd-polluted plants the pollen grains and anther seem to recover the abnormalities caused by $\mathrm{Cd}$ following the decrease in $\mathrm{Cd}$ concentration observed in seeds (Figure 5G-J). However, foliar application of both Se and Mo together on leaves resulted in more abnormalities in anther and pollen grains (Figure 5K,L).
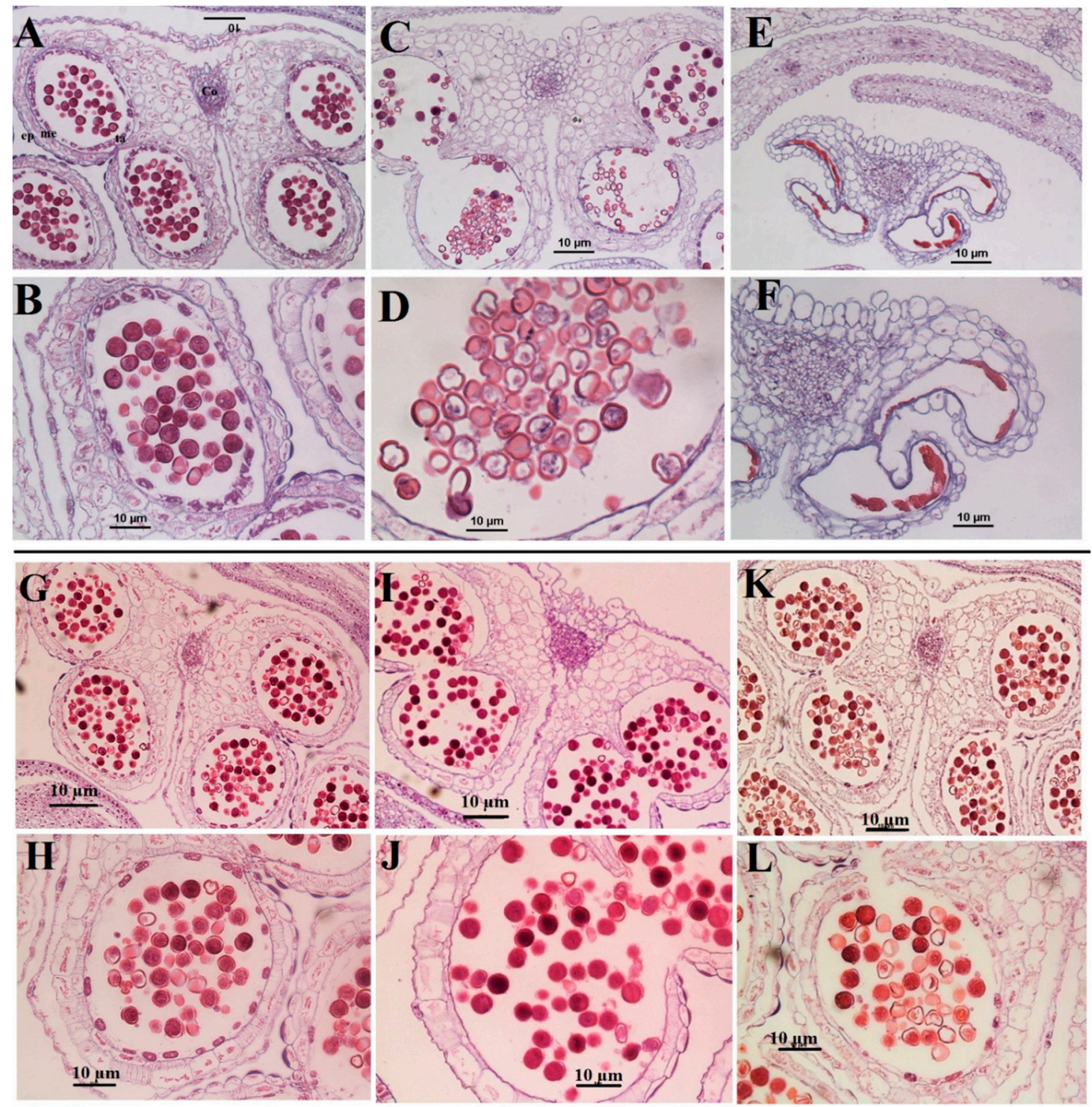

Figure 5. Transverse sections through distinct anther of B. napus. Collected from; CK (A,B), Cd-treated plants $(\mathbf{C}-\mathbf{F}), \mathrm{Cd}+\mathrm{Se}(\mathbf{G}, \mathbf{H}), \mathrm{Cd}+\mathrm{Mo}(\mathbf{I}, \mathbf{J}), \mathrm{Cd}+\mathrm{Se}+\mathrm{Mo}(\mathbf{K}, \mathbf{L})$. Plants were treated with foliar spray of Se $(1 \mathrm{mg} / \mathrm{L})$ and /or Mo $(0.3 \mathrm{mg} / \mathrm{L})$ in absence or presence of Cd stress $(5 \mathrm{mg} / \mathrm{kg})$. Pollen grains are spherical in both polar and equatorial view, with dense cytoplasm and a prominent centrally located nucleus. co: connective, ep: epidermis, me: middle layer, and ta: tapetum. Bar is $10 \mu \mathrm{m}$. 


\subsubsection{Scanning Electron Microscopy}

The pollen grains were further observed by scanning electron microscopy (SEM) to investigate the effects of heavy metals on their morphology. Results from this observation are shown in Figure 6. The morphology of pollen grains was found presenting colpate, prolate, and reticulate sculpture. Pollen grains from Cd-stressed samples displayed thicker exine and raised muri than pollen grains of control plants. In addition, some pollen became sterile devoid of tryphine in the tectal cavities. Finally, an unusual adhesion of pollens collected from Cd-stressed samples was also detected. Similar to microscopic studies, SEM confirmed that in Cd contaminated soil, Se and Mo foliar application could release the toxic symptoms in pollen grains when they are being sprayed alone. However combined usage of them presents negative effect on pollen grains morphology.
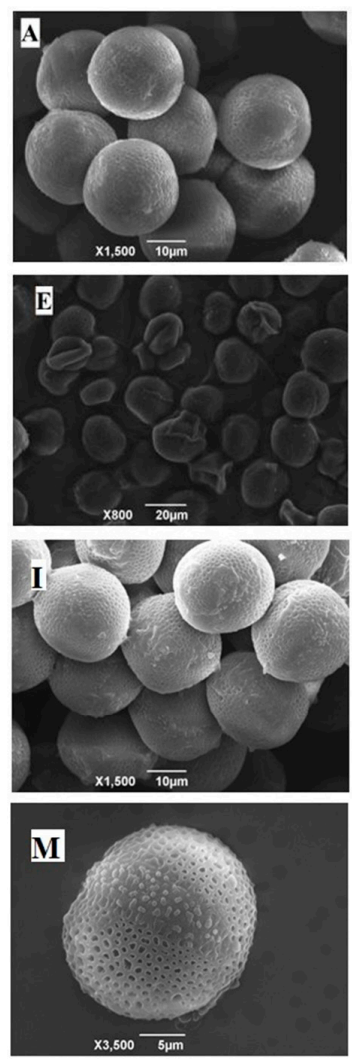
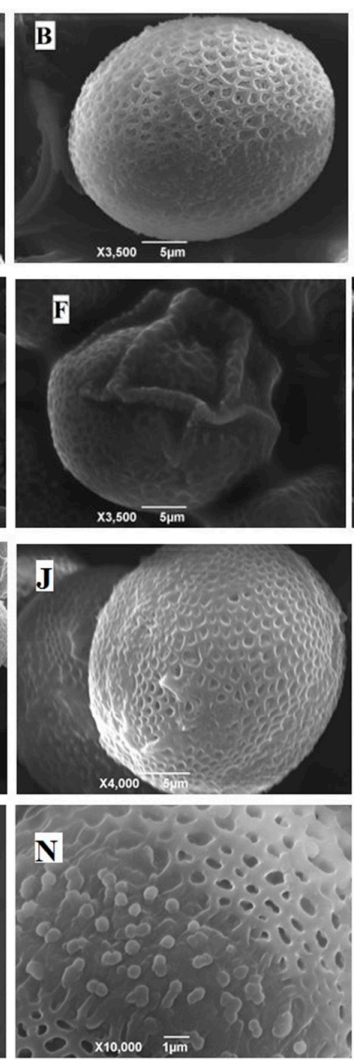
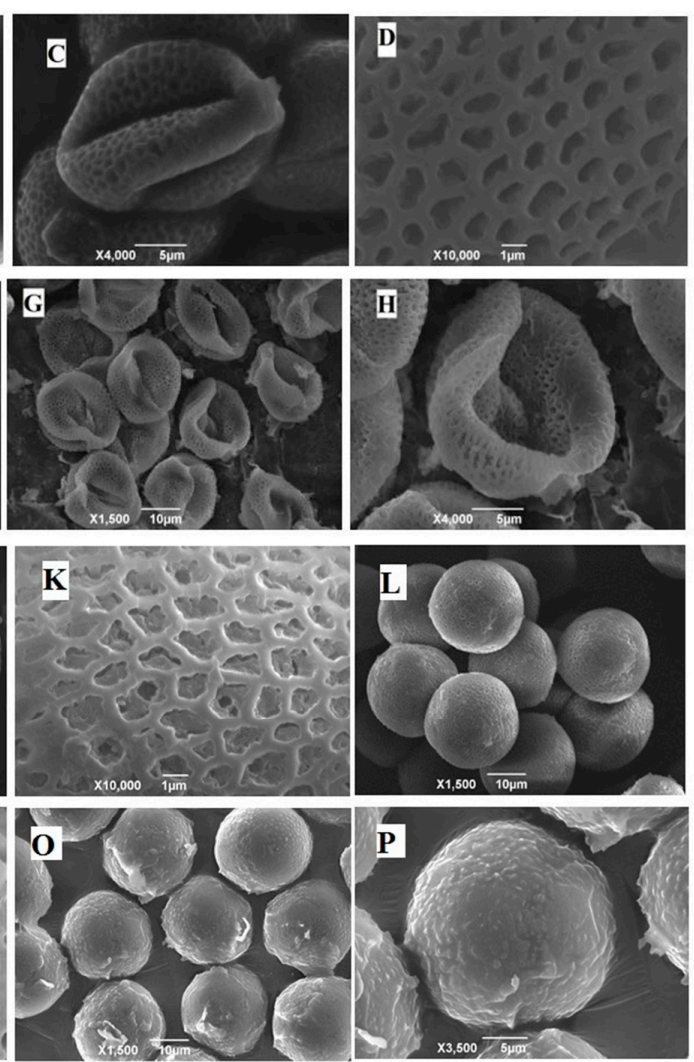

Figure 6. Scanning electron micrographs of B. napus' pollen grains. Control (A-D), plants treated with $\mathrm{Cd}(\mathbf{E}-\mathbf{H}), \mathrm{Cd}+\mathrm{Se}(\mathbf{I}-\mathbf{K}), \mathrm{Cd}+\mathrm{Mo}(\mathbf{L}-\mathbf{N})$, and $\mathrm{Cd}+\mathrm{Se}+\mathrm{Mo}(\mathbf{O}, \mathbf{P})$. Plants were treated with foliar spray of Se (1 mg/L) and/or Mo $(0.3 \mathrm{mg} / \mathrm{L})$ in absence or presence of Cd stress $(5 \mathrm{mg} / \mathrm{kg})$.

\subsection{Pollen Grains Fertility by $I_{2} / K I$ (Iodine) Staining}

Pollen viability refers to the ability of pollen grains to complete post-pollination process and to achieve fertilization. The viability of pollen grains collected from all the treatments was checked and the results are shown in Figure 7. In this test, mature pollens are easily distinguished from the immature ones by color, while normal pollens (mature) stain black to dark brown; abnormal ones (immature) stain orange to red. Pollens from control plants have uniform shape, however, burst pollens are sometimes observed in those samples collected from plants exposed to Cd stress (Figure 7E,F). In addition, viability percentages of pollen grains were reduced proportionally under $\mathrm{Cd}$ stress. However, individual application of Se and Mo reduces the number of abnormal pollen grains, while combined application of both in the presence or absence of $\mathrm{Cd}$ increases the percentage of the abnormal pollen (Figure 8). This result shows that foliar application of Se and Mo together at these concentrations has a toxic effect on pollen grains similar to that of $\mathrm{Cd}$. 


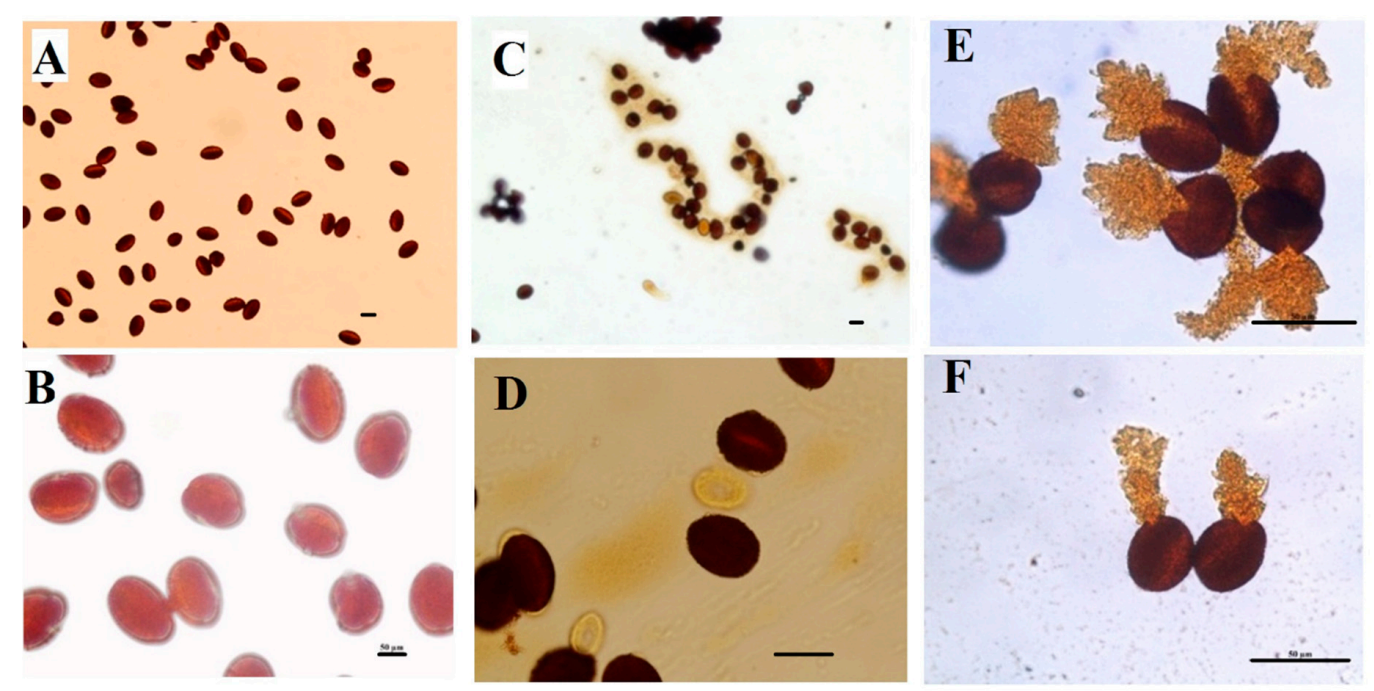

Figure 7. Pollen fertility of $B$. napus' pollen grains. $\mathrm{I}_{2} / \mathrm{KI}$ staining for starch, normal mature pollen grains containing starch granules stain black or dark brown; however, the immature pollen grains appear orange to red; CK (A,B) and Cd-treated plants $(\mathbf{C}-\mathbf{F})$. Pollen from control have uniform shape, but $\mathrm{Cd}$ treated plants sometimes have burst pollen. Pollens were collected from plants treated with foliar spray of Se (1 mg/L) and/or Mo $(0.3 \mathrm{mg} / \mathrm{L})$ in the absence or presence of Cd stress $(5 \mathrm{mg} / \mathrm{kg})$. Scale bar: $50 \mu \mathrm{m}$.

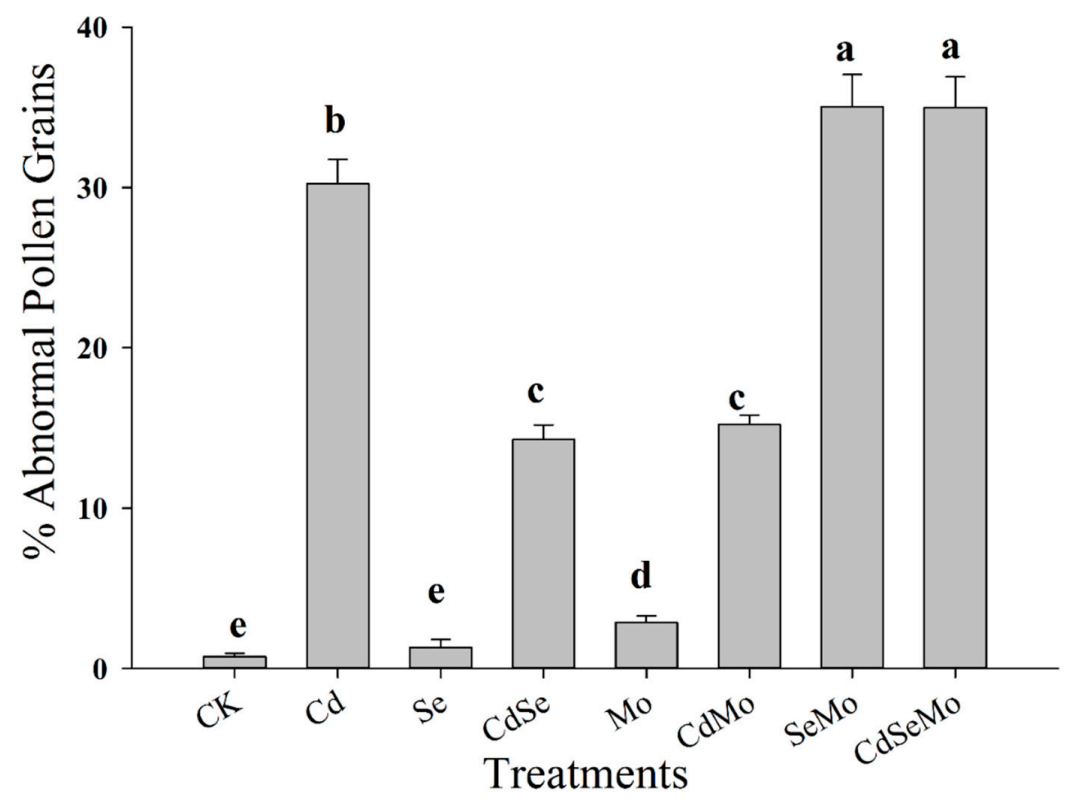

Figure 8. Effect of cadmium, selenium, and molybdneum on \% of abnormal pollen grains in B. napus. Pollens were collected from plants treated with foliar spray of Se $(1 \mathrm{mg} / \mathrm{L})$ and/or Mo $(0.3 \mathrm{mg} / \mathrm{L})$ in the absence or presence of $\mathrm{Cd}$ stress $(5 \mathrm{mg} / \mathrm{kg})$. Different letters indicate significant differences at $(p<0.05)$.

\subsection{Pollen Germination and Pollen Tube Growth In Vitro}

The effect of cadmium ions on the in vitro pollen germination rate of $B$. napus was investigated by light microscopy. In vitro pollen germination of $B$. napus under control conditions is characterized by around $75 \%$ of all cultured pollen grains that had germinated, indicating a high potency of the pollen grains used in the present study and the suitability of the used germination medium. To determine the toxic levels of $\mathrm{Cd}$ on pollen grains, a series of experiments were conducted where pollen grains were 
allowed to germinate in culture media containing cadmium at different concentrations, and the results showed that low $\mathrm{Cd}$ concentrations up to $100 \mu \mathrm{M}$ enhance the pollen germination rate. However, the pollen tube was sometimes noticed to have a swollen tip (Figure 9C,D), which was absent in the control. Pollen tubes of control experiments tend to grow straight with only an occasional change in direction. In contrast, in germination medium containing $\mathrm{Cd}$, even at the low concentrations which displayed an increase in pollen germination rate; the pollen tubes grow extremely contorted. At concentrations higher than $100 \mu \mathrm{M}$, cadmium treatment inhibited pollen germination and tube growth in a dose-dependent manner. In the second set of experiments, three concentrations of Se and Mo were independently checked to reach the best concentration that would positively affect the pollen germination rate and pollen tube growth. We observed that high concentrations of Se $(20 \mu \mathrm{M})$ or Mo $(10 \mu \mathrm{M})$ have significantly inhibited the pollen germination rate and affect the pollen tube growth. From this preliminary experiment, we have determined that, for B. Napus, $10 \mu \mathrm{M}$ Se and $1 \mu \mathrm{M}$ Mo are the optimum stimulatory concentration for in vitro pollen grain germination, while $500 \mu \mathrm{M}$ of $\mathrm{Cd}$ is highly toxic and prevents the pollen germination. Thereafter, pollen was germinated under $\mathrm{Cd}$ stress of $500 \mu \mathrm{M}$ in the presence of Se $(10 \mu \mathrm{M})$ and / or Mo $(1 \mu \mathrm{M})$. Germination rate decreased in Cd treatment to less than $2.5 \%$, but it increased when Se or Mo was added to the germination medium to reach $66.2 \%$ and $39.4 \%$, respectively (Figure 10 ). When pollens were germinated in a medium containing, both selenium and molybdenum, the improvement in the germination rate was much lower than in the case of either Se or Mo alone.
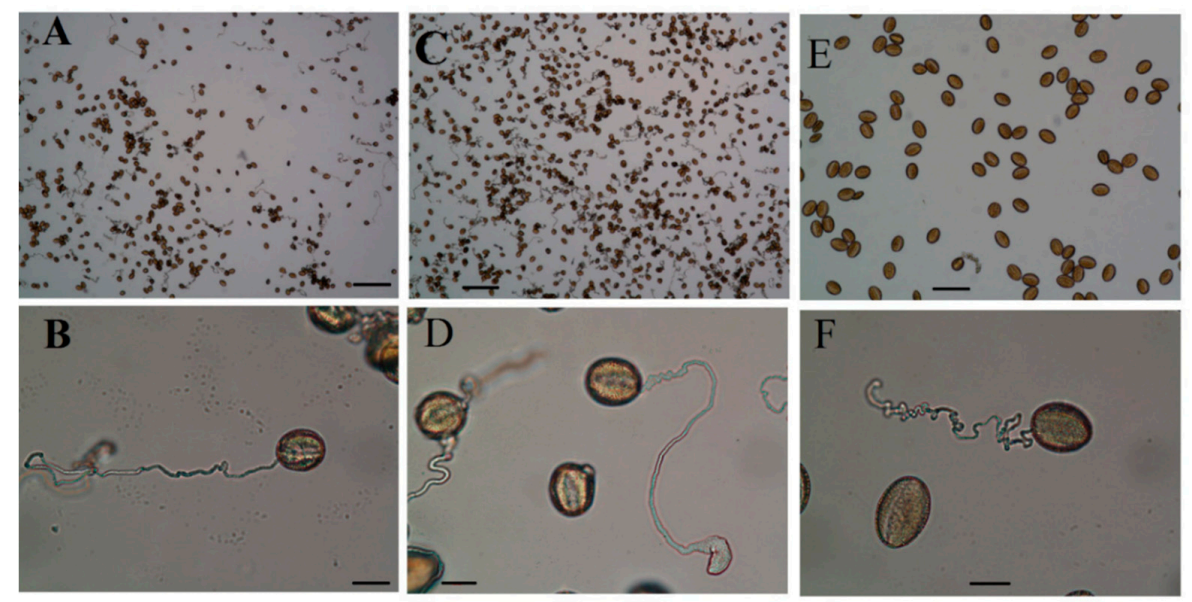

Figure 9. Effect of $\mathrm{Cd}$ on in vitro germination of pollen grains in B. napus. Control (A,B), $100 \mu \mathrm{M}$ cadmium-treated sample (C,D), $500 \mu \mathrm{M}$ cadmium-treated sample (E,F), pollens are germinated in a culture medium contains polyethylene glycol $4000(20 \%)$ and sucrose $(5 \%)$. Scale bar: $20 \mu \mathrm{m}$.

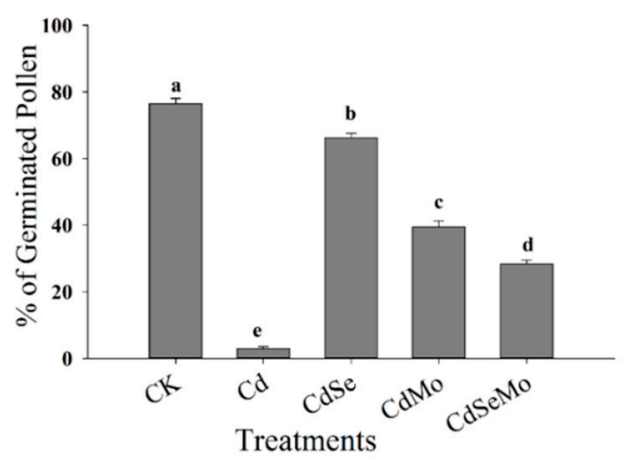

Figure 10. In vitro germination (\%) of pollen grains under $\mathrm{Cd}$ stress. Pollens are germinated in a culture medium contains polyethylene glycol $4000(20 \%)$ and sucrose (5\%) under $500 \mu \mathrm{M} \mathrm{Cd}$ in the presence of Se $(10 \mu \mathrm{M})$ and/or $(1 \mu \mathrm{M})$ Mo. Different letters indicate significant differences at $(p<0.05)$. 


\subsection{Relative Expression Analysis of Genes Related to Cd Uptake, Transport, and Detoxification}

To investigate how Se and Mo application could control Cd-uptake and its further transport at the genetic level, we have examined the relative expression of several genes that might be involved in $\mathrm{Cd}$ uptake or detoxification such as IRTI, HMA2, HMA3, and HMA4 in those treatments where plants were exposed to cadmium stress. However, studying those genes controlling $\mathrm{Cd}$ uptake and translocation could not completely explain the protective role of Se on pollen grains and the low $\mathrm{Cd}$ in seed. Therefore, another gene i.e., PCS1 was considered which is known to provide $\mathrm{Cd}$ tolerance and control $\mathrm{Cd}$ accumulation in seeds. The expression of the IRT1 gene in roots significantly increased $(p<0.01)$ in the presence of $\mathrm{Se}$, as compared to $\mathrm{Cd}$ only. However, no significant differences were observed in IRT1 expressions between other treatments, i.e., $\mathrm{Cd}, \mathrm{Cd}+\mathrm{Mo}$, and $\mathrm{Cd}+\mathrm{Se}+\mathrm{Mo}$ (Figure 11A). HMA2 and $H M A 4$ are expressed in the plant roots 10 times higher than in leaves. In roots, both of them showed the same trend where the genes are overexpressed in $\mathrm{Cd}+$ Se treatment. Mo treatments did not result in a significant change in the two genes expressions when applied alone, and it even down-regulates HMA2 and HMA4 expressions when it was amended with Se (Figure 11B,C).

A

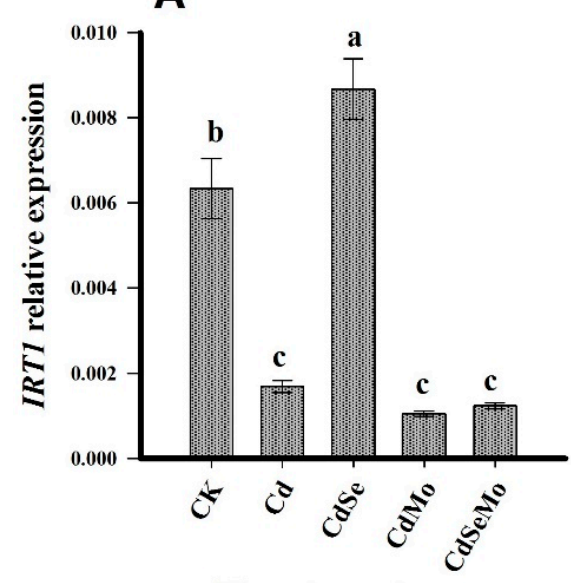

Treatments
B

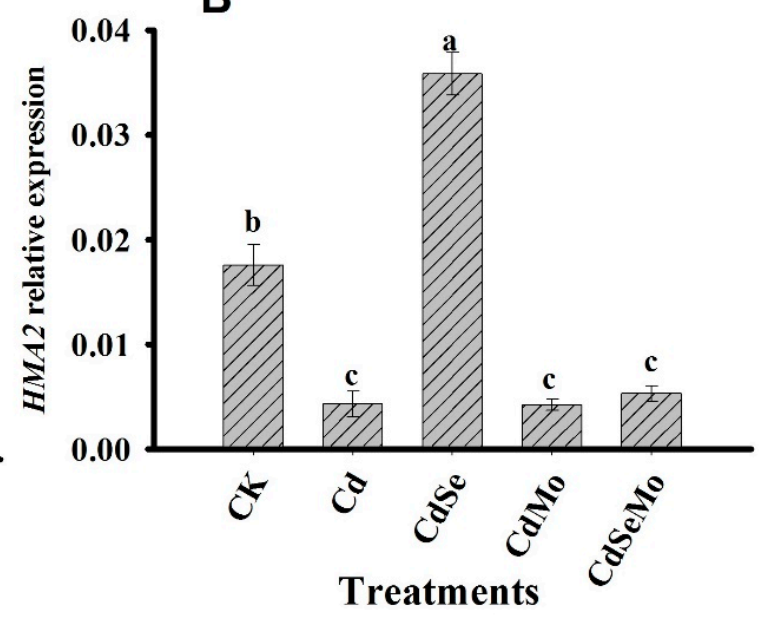

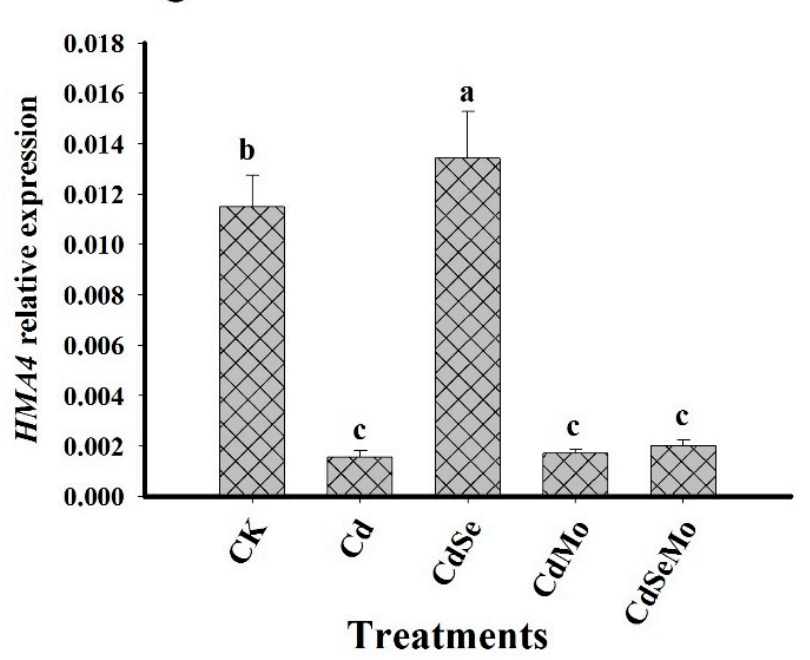

Figure 11. Expression profiles of IRT1 (A), HMA2 (B), and HMA4 (C) in roots of B. napus. Vertical bars indicate standard error of each mean $(n=3)$. Different letters within a column indicate significant differences between treatments at $(p<0.05)$. The relative expression levels were calculated by comparing the cycle thresholds (CTs) of the target genes with that of the reference gene BnActin using the $2^{-\Delta \Delta C t}$ method. 
Interestingly, HMA3 was found to be strongly expressed in leaves hundred-fold higher than its expression in roots. In leaves, Mo application enhanced $H M A 3$ expression, while Se has no substantial effect on it (Figure 12A,B). These results interpret the high Cd content in the plant root and shoot in the presence of $\mathrm{Se}$, which is due to the enhanced genes expressions responsible for $\mathrm{Cd}$ uptake, i.e., IRT1 and Cd translocation from root to shoot, i.e., HMA2 and HMA4. In case of Mo application, Cd uptake was reduced as observed by the low expression of IRT1. However, Cd translocation from root to shoot was not much affected, at least via HMA2 and HMA4 genes. Phytochelatins (PCs) are glutathione-derived peptides and its biosynthesis is considered one of the most important mechanisms that contribute to $\mathrm{Cd}$ accumulation and tolerance in plants. In our study, $\mathrm{Cd}$ exposure significantly stimulate the expression of PCS1 in the plant leaves. Treating the plants with either Se or Mo enhanced the expression of PCS1 over Cd-treatment alone, at a similar level. However, applying Se and Mo together did not enhance PCS1 expression in Cd + Se + Mo treatment, when compared with Cd only (Figure 12C,D). This will lead to PC deficiency which in turn may cause Cd sensitivity, this could explain the negative effect of the combined application of Se and Mo when applied under Cd stress.
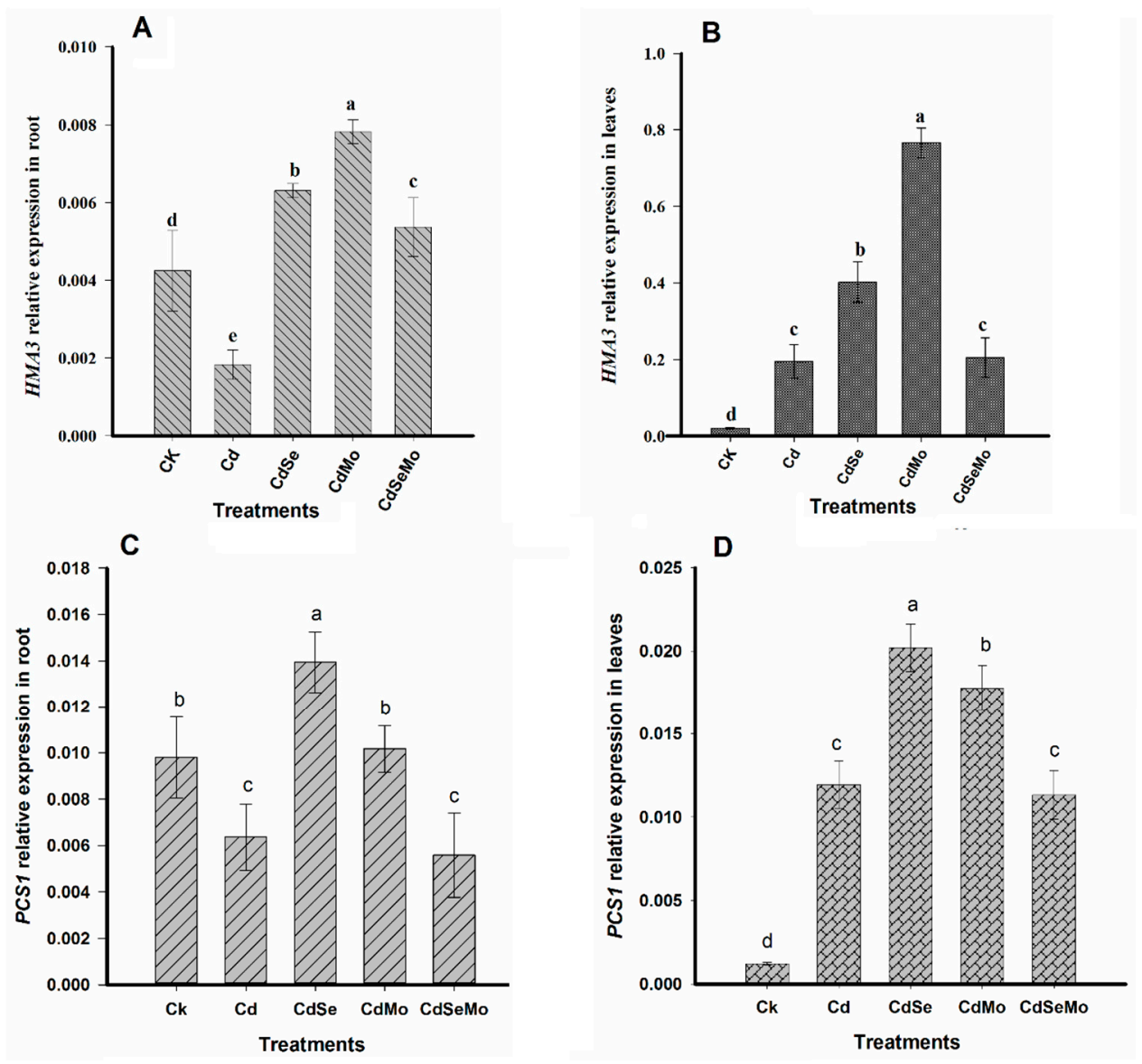

Figure 12. Expression level of HMA3 in root (A) and leaves (B), and PCS1 in root (C) and leaves (D) of $B$. napus vertical bars indicate standard error of each mean $(n=3)$. Different letters within a column indicate significant differences between treatments at $(p<0.05)$. The relative expression levels were calculated by comparing the cycle thresholds (CTs) of the target genes with that of the reference gene BnActin using the $2^{-\Delta \Delta C t}$ method.

\section{Discussion}

It is well established that the production of plant biomass is an important indicator for evaluating plant tolerance to heavy metal stress, such as Cd [37]. In our study, Cd at $5 \mathrm{mg} / \mathrm{kg}$ soil reduced the growth of $B$. napus which consequently leads to the reduction of its tissues biomass. Plant growth 
inhibition by $\mathrm{Cd}$ may be due to the inhibition in cell division and its toxic effects on the function of some key enzymes involved in plant metabolism. Se or Mo foliar fertilization has improved the plant growth. Combined application of both Se and Mo solutions significantly reduced the overall plant biomass, regardless of $\mathrm{Cd}$ content $(0$ or $5 \mathrm{mg} / \mathrm{kg}$ ). Several studies have demonstrated that Se can play diverse beneficial effects at low concentrations including growth-promoting activities of higher plants [38]. Molybdenum, as one of the micronutrients that plants need in very small amounts for normal growth, has also been proved to improve the growth parameters in different plants, such as Helianthus annuus L. [39,40], Brassica napus [41], and other plants. The stimulating effect of Mo on plant biomass might be due to its role as a cofactor for enzymes involved in nitrate metabolism (such as nitrate reductase and glutamine synthetase) and synthesis of amino acids and indole acetic acid [20]. Moreover, Mo application was found to enhance salinity stress tolerance in Chinese cabbage by increasing the photosynthesis rate and the ionic homeostasis adjustment [42]. In wheat, Mo supplementation increased the activities and transcripts of antioxidant enzymes, decreased $\mathrm{H}_{2} \mathrm{O}_{2}$ and MDA contents, and elevated NO production, implying that Mo-induced antioxidant defense may be related to NO signal [43]. Zhang et al., reported that when Se and Mo were used independently in the growth medium at $0.01 \mathrm{mg} / \mathrm{L}$ concentration, it slightly enhanced the growth of Chinese cabbage, however, at slightly higher Se concentration $0.1 \mathrm{mg} / \mathrm{L}$, it significantly reduces the plant growth as indicated by more than $10 \%$ decrease in shoot DW, as compared to using Mo only [44]. The reduction in plant biomass in case of combined Se and Mo application can be due to more than one reason. Firstly, several reports have verified that both Mo and Se are transported through the plant via sulphate and phosphate transporters. Thus, these anions will compete with each other to interact with the transporters, which might affect the absorption of any of them, as well as sulfate transport $[45,46]$. Indeed, from our results we can observe that Mo concentration was significantly reduced in both stem and seed in Se + Mo treatment. This decrease in Mo concentration might affect many physiological processes, due to Mo incorporation into molybdopterin, an essential cofactor for enzymes involved in sulfite detoxification, purine catabolism, nitrate assimilation, and abscisic acid biosynthesis. In addition, Schiavon et al., reported that selenate and molybdate alter sulfate transport and assimilation, thus treating Brassica juncea with either Se or Mo led to a considerable decrease of sulphate uptake, this effect might be more pronounced in case of the combined application of both Se and Mo [47]. This was likely because selenate and molybdate competed with sulfate for access to the $\mathrm{S}$ metabolic pathway. In addition, selenium competition is known to cause a disruption of $\mathrm{S}$ metabolism and repressed synthesis of reduced S-containing compounds, such as Cys and GSH. Likewise, the mean shoot and root biomass of Astragali species was significantly reduced when treated with Se and Mo, regardless of whether the species are Se-hyperaccumulator or non-accumulator, with also reduced $S$ assimilation in Se-non-accumulators [48].

Mo foliar fertilization decreased the plant Cd uptake as illustrated by its low concentration in root and stem. On the other hand, Cd content in both root and shoot was significantly increased with Se foliar application. Reports have shown that proper doses of Se can protect plants against the damage caused by heavy metals/metalloids and decrease its uptake and accumulation in the plant tissues, including Cd [49,50], Pb [51,52], Cr [53], Ni [54], Hg [55], Cu [56], As [57], and Sb [58]. The mechanisms of heavy metal detoxification by Se might be related to the inhibition of uptake and translocation of heavy metals from the roots to aboveground and/or the speciation transformation to nontoxic species. However, in some other cases, it was shown that Se can stimulate heavy metal accumulation such as $\mathrm{Cd}$ and $\mathrm{Cu}$ in wheat and pea [59], As in Thunbergia alata [60], $\mathrm{Al}$ in ryegrass [61], and $\mathrm{Cd}$ and $\mathrm{Cu}$ in the roots of Sinapis alba L. seedlings [62]. The increase of $\mathrm{Cd}$ accumulation in plant tissues, in our study, in case of Se foliar application is unlikely to be attributed to the improper dose of Se, since Se alone has a positive effect and enhance the plant growth and increase Se content in all plant tissues compared to control. It seems that heavy metal uptake and its translocation depend on several parameters such as plant species and cultivar, the used dose, application method (foliar spray or soil/solution additives), etc. In addition, the decrease of $\mathrm{Cd}$ reaching the plant fruit on applying Se, 
accompanied by the increase of $\mathrm{Cd}$ concentration in root and stem in the same treatment, suggest that the speciation conversion of $\mathrm{Cd}$ into nontoxic species and its sequestration into leaves vacuoles could be the reason of elevating $\mathrm{Cd}$ toxicity and enhancing the plant growth, which is confirmed from the study of metal transporters.

Foliar application of Se and Mo significantly increase their concentrations in all the plant parts, compared to controls, which means that B. napus can effectively take up Se and Mo through foliar application. Furthermore, when Mo is applied with Se, it enhances Se transport from shoot to root and increases Se concentration in root and reduce it in shoot. Zhang et al. [44] found an antagonistic relationship between Se and Mo uptake in Chinese cabbage when both were supplied in solution culture. Se concentrations in shoots and roots were significantly inhibited by application of Mo. In a recent study, application of Mo increased Se concentrations in pepper fruit, stem, leaf, and root in Capsicum frutescens L. [63], which is consistent with our observation. Mo uptake was found to increase under Cd stress, without a clear impact of $\mathrm{Cd}$ on the Mo translocation from shoot to root. Se application resulted in a decrease of Mo concentration in stem, glume, and seeds, but the root Mo content was increased. These results suggest that Se enhances Mo transfer from shoot to root which conforms to that found by others $[45,46]$.

Microscopic studies revealed the appearance of several toxic symptoms on pollen grains and anthers collected from those plants grown merely under Cd stress which eventually affect B. napus fertility. Similar observations were reported in Chenopodium botrys L. grown in a mine area polluted with $\mathrm{Fe}, \mathrm{Mn}$, and $\mathrm{Zn}$ [64]. Lead was also reported to have toxic effects on the pollen grains in Matricaria chamomilla in an in vivo experiment; the toxic effects included decrease in the size and diameter of pollen sac wall, along with change of the spine shape [65]. On the other hand, some results showed that $\mathrm{Cd}$ exposure had no effect on in vivo pollen germination of Pisum sativum L. exposed to $7 \mathrm{mg} / \mathrm{kg} \mathrm{Cd}$ in soil, however, the same study revealed that a Cd concentration at $10 \mu \mathrm{g} / \mathrm{mL}$ drastically inhibited the pollen germination rate in the in vitro experiment, reducing it to $11 \%$ compared to $90 \%$ in control [11]. Abnormalities development of pollen grains is not observed under heavy metal stress only, but other stress such as salinity cause the destruction of the anther wall and both the degeneration and production of abnormal pollen grains [66]. Results from SEM has also shown that pollen grain of Brassica napus has similar morphology to that of Arabidopsis [67]. Previous studies have shown that Se treatment could raise respiratory activity in leaves and flowers in Brassica napus, which may have contributed in turn to increase the seed production by $43 \%$ [11]. Several studies have shown a strong correlation between mitochondrial function and pollen viability [68]. Thus, it is expected that increased mitochondrial activity in the leaves and flowers would be reflected in pollen viability in the Se-treated plants. Additionally, Se was found to strongly counteract the ROS accumulation in olive pollen grains under draught stress and consequently to enhance pollen viability [69]. Mo deficiency is reported to have striking effect on pollen formation in maize. Their pollen grains were smaller, free of starch, have much lower invertase activity, and showed very poor germination [22,70].

Generally, Cd strongly inhibits pollen germination and tube growth $[9,11,71,72]$. However, low concentrations of $\mathrm{Cd}\left(10^{-12}-10^{-10} \mathrm{M}\right)$ are reported to have stimulatory effect on growth rate and tube elongation [73], which was attributed to stimulating the enzymatic activities at the low concentrations $[9,74]$. However, high concentrations of heavy metals inhibit the enzymatic activities and, thus, might constrict the pollen germination. In our study, low concentrations of Cd $(0-100 \mu \mathrm{M})$ was found to stimulate pollen germination and tube growth, however, the pollen tubes showed a range of strong morphological abnormalities, characterized by irregular or anomalous growth, such as swelling at the tip of the pollen tube and extremely contorted growth. However, stimulation of the germination rate was observed up to $10^{-4} \mathrm{M}$ Cd during the initial (1-2 h) stages of pollen tube growth, which is a relatively high concentration compared to some reports of $10^{-10} \mathrm{M} \mathrm{Cd}$, for Lilium longiflorum and Nicotiana tabacum pollen grains [73] and $\sim 10^{-6} \mathrm{M} \mathrm{Cd}$ for Plantago depressa [72]. In the current study, lower concentrations of $\mathrm{Cd}$ have greatly affected the plant growth (plant biomasses) and pollen morphology as previously described, while in vitro treatments at higher concentrations up to $100 \mu \mathrm{M}$ 
stimulates the pollen germination rate, though it causes some abnormalities for pollen tube, which demonstrates that in the in vitro experiments pollen may be less sensitive to $\mathrm{Cd}$ than in vivo. Several studies have correlated the negative effects of the heavy metals on the pollen germination and pollen tube growth to several factors, including enzyme activity decline, preventing DNA replication and protein synthesis in plants which, in turn, affect pollen germination [75]. In Picea wilsonii, Cd stress strongly inhibited pollen germination and tube growth by disrupting the endomembrane organelles, inhibiting endo/exocytosis, and forming acidic vacuoles, resulting in swollen tube tips and irregularly broadened tube diameters [13].

Low doses of Se $(10 \mu \mathrm{M})$ and Mo $(1 \mu \mathrm{M})$ had a positive effect on the pollen germination and pollen tube growth under Cd stress, which suggest that both Se and Mo can counteract the damage effects of $\mathrm{Cd}$ in the in vitro pollen germination. Similar findings have been reported where Se was found to promote the germination of olive pollen in both drought stressed and non-stressed conditions [69]. The authors further checked $\mathrm{H}_{2} \mathrm{O}_{2}$ levels in the pollen under draught stress to conclude that the addition of Se strongly counteracted the ROS accumulation, thus, the amount released from pollen of stressed plants was similar to control plants [69]. Mo has also been described to promote pollen germination at low concentrations in strawberry, but at higher concentrations it was found to decrease it [76]. Similarly, Raohavan and Baruah found that ammonium molybdate stimulated germination and growth of Areca catechu pollen even in the absence of boron, which is essential for pollen germination media used in their study [77]. On the other hand, molybdenum was claimed not to have any stimulation effect upon either germination or growth in Setaria sphacelate [78]. Thus, the impact of Mo on pollen germination and pollen tube growth might be affected by some other parameters and might strongly depend on the plant species.

Heavy metals uptake and transport in plants are controlled by a group of metal transporters. Manipulation of these transporters activities could confer or weaken the plant tolerance to Cd stress. IRT1 is responsible for uptake of iron from soil, however it can mediate variety of other heavy metals, including the essential metals such as zinc and manganese as well as toxic metal such as cadmium [79]. In A. thaliana, AtIRT1 has been identified for mediating $\mathrm{Cd}$ uptake from soils and could be regulated by overexpression or deletion mutation [80]. In A. thaliana, AtIRT1-overexpressing plants accumulated more amounts of $\mathrm{Cd}$ as compared to wild-type plants [30]. After $\mathrm{Cd}$ absorption through the plant roots, it can then be transferred into plant shoots through the xylem, which contribute to most of the $\mathrm{Cd}$ accumulation in the plant shoots [81]. In A. thaliana, AtHMA2 and AtHMA4 pump Cd into the xylem, which is necessary for root-to-shoot Cd translocation [31,32]. Overexpression of AtHMA4 increased root-to-shoot $\mathrm{Cd} / \mathrm{Zn}$-transport and, thus, enhanced the plant metal tolerance [82], whereas disruption of AtHMA4 function led to hypersensitivity to $\mathrm{Cd}$ and $\mathrm{Zn}$ in A. thaliana [83]. In Brassica napus, high expression of IRT1 in root was responsible for the high Cd uptake of one cultivar (L338), as compared to another one (L351). However, the L351 accumulated more Cd in the plant shoots as compared to L338 cultivar, which was due to the different efficiency of Cd translocation by the xylem. This was further explained as result of the higher expression of HMA2 and HMA4, in L351 as compared to L338 [84].

In our study, Se enhanced the expression of IRT1 in root tissues leading to enhanced Cd-uptake by the roots, which could explain the high Cd content in $\mathrm{Cd}+$ Se treatment in roots as compared to Cd only. The expression of HMA2 and HMA4 was significantly reduced under Cd stress, except on applying Se, which up-regulates these genes leading to more root-to-shoot translocation of $\mathrm{Cd}$ in a good agreement with the high Cd concentration accumulated in stem under the same treatment. There are several reports in literature indicating that the increased expression level of HMA2 or HMA4 induced $\mathrm{Cd}$ xylem uploading for translocation to the shoots, leading to higher $\mathrm{Cd}$ content in plant shoots [82,85]. In contrast, Mo application down-regulated IRT1 gene expression resulting in lower Cd uptake by the plant roots. Additionally, it did not enhance genes responsible for Cd-translocation, i.e., HMA2 and HMA4, which interpret the lower accumulation of $\mathrm{Cd}$ in plant stems in $\mathrm{Cd}+\mathrm{Mo}$ treatment. 
On the other hand, our results indicate that HMA3 was induced in the plant tissues under $\mathrm{Cd}$ treatment, especially on applying Mo. The overexpression was more pronounced in leaves as compared to roots. Basically, $H M A 3$ expression level varies from Cd-hyperaccumulators to non-hyperaccumulators. Thus, high expression of this gene is required for $\mathrm{Cd}$ hypertolerance in the Cd-hyperaccumulation for sequestering $\mathrm{Cd}$ into leaves' vacuoles, particularly in young leaf cells $[86,87]$. However, the situation is different in Cd-non-hyperaccumulators, where it displays higher expression levels in the plant root than shoot, resulting in higher $\mathrm{Cd}$ concentration in the plant root, and lower root-shoot Cd translocation [87,88]. For instance, in Oryza sativa, overexpression of OsHMA3 reduced the accumulated Cd in grains and enhances the plant tolerance to Cd $[89,90]$. Therefore, B. napus, as Cd-hyperaccumulator, is highly expected to have higher HMA3 expression in leaf tissues as compared to roots.

Phytochelatins (PCs) are generally known to have a significant role in heavy metal detoxification in plants; either via shuttling PC-Cd complexes into plant cell vacuoles or through the long-distance transport in the root-to-shoot and shoot-to-root directions [35]. PCs are essential for Cd tolerance in plants and all the mutants that are unable to synthesize those peptides are Cd-hypersensitive [91]. Both Se and Mo up-regulate the expression of PCS1 in the plant tissues, which would enhance the plant tolerance to $\mathrm{Cd}$. This $\mathrm{Cd}$-tolerance enhanced the plant growth even if the $\mathrm{Cd}$ content was high, like in the case of $\mathrm{Cd}+\mathrm{Se}$ treatment, as compared to Cd only. However, applying Se and Mo together down-regulates the expression of PCS1 which accounts for the plant Cd-sensitivity and the retarded growth. The essential roles of PCs in metal detoxification by plant cells are as known as the Cd-tolerance with the overexpression of PC synthase genes. In B. napus, high levels of PCs were detected in the phloem sap when the plant was exposed to Cd stress [35].

In summary, Se and Mo foliar application could alleviate Cd toxicity in B. napus and limit its accumulation in the plant seeds which are mainly used as a source of oil. Cd toxicity and the protective role of either Se or Mo could be clearly observed in the pollen grains morphology, fertility, and the in vitro germination rate. The mechanisms by which Se and Mo control Cd reaching the plant seeds is different and it does not depend only on controlling Cd-uptake by the plant root. Metal transporters specially HMA3 and synthesis of phytochelatins are two key mechanisms the plant utilize to cope with Cd stress.

\section{Materials and Methods}

\subsection{Soil Properties, Selected Plant Species, and Experimental Setup}

\subsubsection{Soil Properties}

Soil used in this experiment was collected from the test field in Huazhong Agricultural University, Wuhan, China. The soil sample was transferred to the greenhouse of the Micro-element Research Center $\left(30^{\circ} 28^{\prime \prime} 26^{\prime \prime} \mathrm{N}, 114^{\circ} 20^{\prime} 51^{\prime \prime} \mathrm{E}\right.$, and $30 \mathrm{~m}$ above sea level) for grinding and sieving. Soil analyses were performed at the beginning to test different parameters following different methods. Physicochemical characteristics of the soil were as follow: $\mathrm{pH}$ 7.12; Organic matter, $13.72 \mathrm{~g} / \mathrm{kg}$; available potassium, $193.48 \mathrm{mg} / \mathrm{kg}$; alkaline hydrolysis nitrogen, $52.33 \mathrm{mg} / \mathrm{kg}$; available Se, $0.022 \mathrm{mg} / \mathrm{kg}$; available Mo, $0.068 \mathrm{mg} / \mathrm{kg}$; total Cd, $0.072 \mathrm{mg} / \mathrm{kg}$; and Olsen-P, $16.57 \mathrm{mg} / \mathrm{kg}$.

\subsubsection{Selected Plants}

The L351 rape genotype of high Cd accumulation ability in shoots and low $\mathrm{Cd}$ accumulation in roots was used in this study. In our previous study, 165 different rape lines were selected for pot and hydroponic culture experiments to investigate the $\mathrm{Cd}$ concentrations in different parts of rapes under $\mathrm{Cd}$ stress to screen high/low $\mathrm{Cd}$ accumulating rape lines. Finally, one rape genotype of high $\mathrm{Cd}$ accumulation (L351) was used in this experiment [84]. 


\subsubsection{Pot Setup and Monitoring}

The polluted soil required for the pot experiment was prepared by mixing the soil with $5 \mathrm{mg} \cdot \mathrm{Cd} / \mathrm{kg}$. soil cadmium chloride hemipentahydrate $\left(\mathrm{CdCl}_{2} \times 2.5 \mathrm{H}_{2} \mathrm{O}, 98 \%\right.$, purity) in aqueous solution. The $\mathrm{Cd}$ solution was applied to the soil surface in polyethylene pots $(20 \mathrm{~cm}$ diameter and $15 \mathrm{~cm}$ depth) and thoroughly mixed, then saturated with water, and air dried at room temperature. The wetting-drying mixing process was repeated to ensure soil equilibrium for a two-month period under natural light at a minimum temperature of $10-11^{\circ} \mathrm{C}$, a maximum of $25-30^{\circ} \mathrm{C}$, and a relative humidity of about $30-40 \%$.

The experiment was set up into eight treatments with four replicates, including control, noted as $\mathrm{Ck}$, selenium only (Se), molybdenum only (Mo), both selenium and molybdenum ( $\mathrm{Se}+\mathrm{Mo}), \mathrm{Cd}$ only (Cd), Cd with Se $(\mathrm{Cd}+\mathrm{Se})$, Cd with Mo $(\mathrm{Cd}+\mathrm{Mo})$, and $\mathrm{Cd}$ with both Se and $\mathrm{Mo}(\mathrm{Cd}+\mathrm{Se}+\mathrm{Mo})$. In each replicate basal nutrients $(\mathrm{N}, \mathrm{P}$, and $\mathrm{K})$ and others microelements were supplemented with a given and measured quantity. During fertilizers application, the soil in the pots was covered with polythene bags to avoid the entrance of either fertilizer to the soil.

The seeds were sown in each pot and the seedlings were thinned to two per pot. The seedlings were allowed to grow for 30 days in the pots for acclimatization before foliar spray of fertilizers to be applied. The foliar application of Se and Mo was carried out using $1.0 \mathrm{mg} \mathrm{Se} \mathrm{L}^{-1}$ (as sodium selenite $\left(\mathrm{NaSeO}_{3}\right)$ and $0.3 \mathrm{mg} \mathrm{L}^{-1} \mathrm{Mo}$ (as ammonium molybdate $\left.\left[\left(\mathrm{NH}_{4}\right)_{6} \mathrm{Mo}_{7} \mathrm{O}_{24} \cdot 4 \mathrm{H}_{2} \mathrm{O}\right]\right)$ solutions. The spraying was performed in the morning on a dry and sunny day and was repeated two times a week for ten weeks. The same amount of distilled water was used for control experiment. At the beginning stage of flowering, the florets $(1-3 \mathrm{~cm})$ were sampled out from both the control and treatments groups. At the same stage, three-plants of every treatment were harvested, roots and leaves were separated, washed, and immersed in liquid nitrogen, and then stored at $-80^{\circ} \mathrm{C}$ for total RNA extraction. At the end of the plant growth period, the roots of all the plants were separated from their shoot and rinsed with tap water to remove adhering soils before being washed with deionized water. All roots were soaked into $20 \mathrm{mmol} / \mathrm{L}$ EDTA-Na 2 solution for $10 \mathrm{~min}$ to remove metal ions from root surfaces. Plant samples were then dried at $65^{\circ} \mathrm{C}$ for one week until they reached a constant weight. Then the dried plant materials were weighed and ground.

\subsection{Pollen Grain Studies}

\subsubsection{Development}

For the characterization of heavy metal effects on pollen developmental stages, anthers, flowers, and young buds were removed from the plants under different treatments. The specimens were fixed in FAA (formaldehyde, glacial acetic acid, and 70\% ethanol, 5:5:90), stored in 70\% ethanol, embedded in paraffin, and then sectioned at $8 \mu \mathrm{m}$ with a Leitz 1512 microtome. Staining was carried out with Mayer's hematoxylin-eosin method [92], and at least 20 flowers were studied under a light microscope (BX51; Olympus, Tokyo, Japan), and differences between pollen grains collected from polluted and non-polluted samples were analyzed.

\subsubsection{Morphology by SEM}

For thorough studies of pollen grains morphology, samples were collected from mature flowers and studied using scanning electron microscope (SEM). Tissues were critical-point dried with liquid $\mathrm{CO}_{2}$, set on aluminum stubs with two-sided tape, coated with gold (Edwards S150B Sputter Coater, BOC Edwards, UK), and observed with a JEOL JSM-6390/LV SEM (JEOL, Japan) at $20 \mathrm{kV}$.

\subsubsection{Fertility Using $\mathrm{I}_{2} / \mathrm{KI}$ Solution}

Flowers from polluted and unpolluted samples were collected, anthers were dissected out and prefixed in $70 \%$ ethanol, then the flowers were placed on a glass slide and the sliced anthers were opened with forceps until they released pollen grains. Then the pollen was stained with $1.0 \% \mathrm{I}_{2} / \mathrm{KI}$ 
solution (1-2 drops on each slide), incubated for $5 \mathrm{~min}$, then observed and photographed. Well-stained (black) and perfect pollen grains were considered as fertile, while the immature pollen grains appeared orange to red [93].

\subsubsection{In Vitro Germination}

To study the protective role of Se and Mo on the in vitro pollen germination rate and pollen tube growth, similar treatments to those in the in vivo experiment were planned. Thus, pollen grains, after hydration, were sown in an aqueous culture medium containing 5\% sucrose and 20\% PEG 4000 [94]. To investigate the metal influence on germination rate, the medium also contained 0 (control) or 10-500 $\mu \mathrm{M}$ cadmium, applied as chloride salt $\left(\mathrm{CdCl}_{2} \times 2.5 \mathrm{H}_{2} \mathrm{O}\right)$, without/with added Se $(1,10$, and $20 \mu \mathrm{M}), \mathrm{Mo}(1,5$ and $10 \mu \mathrm{M})$, or both at the same time. Pollen grains were collected from freshly dehisced anthers on a dry slide and exposed to vapor-phase pre-hydration for 20-30 min in Petri plates lined with moist filter paper. Hydrated pollen grains were cultured in sitting drops $(20 \mu \mathrm{L})$ of germination media, then the slides were incubated at room temperature for $90 \mathrm{~min}$. Germination rate $(\%)$ was calculated based on protuberance of the pollen tube by observing 100 randomly selected pollen grains in each replicate. A pollen grain was considered germinated if the pollen tube length was more than twice the pollen grain diameter [95].

\subsection{Analytical Tests}

To determine total metal content in plant tissues, aqua regia method was used [96]. Hence, approximately $0.5 \mathrm{~g}$ of ground plant sample was digested using $10 \mathrm{~mL}$ of a $\mathrm{HNO}_{3} / \mathrm{HClO}_{4}$ (9:1) mixture at a constant temperature of $200{ }^{\circ} \mathrm{C}$. The sample was heated to the point of white smoke from perchloric acid. The digested solution was cooled and diluted to $25 \mathrm{~mL}$ using deionized water. The diluted solution was filtered and $\mathrm{Cd}$ concentrations were measured using atomic absorption spectroscopy (Z-2000, HITACHI, Japan). A standard material of plant GBW10015 (GSB-6) was used for the quality assurance and quality control of $C d$ analytical procedure with recovery rate of $90 \pm 10 \%$.

For Se concentration measurement, $0.5 \mathrm{~g}$ of a plant sample was digested following the same method described above. However, after heating to the point of white smoke from perchloric acid, $10 \mathrm{~mL}$ of $\mathrm{HCl}$ and water $(1: 1, v / v)$ were added, and then heating continue until white smoke appeared again. The sample was then diluted to $25 \mathrm{~mL}$ using deionized water and filtrated. The obtained solution was used for Se determination by dual-hydride generation atomic fluorescence spectrometry (AFS-9700, Haiguang, China) following the hydride generation-atomic fluorescence method (GB/T21729. 2008) with the same standard material used for $\mathrm{Cd}$.

Mo determination was carried out according to the procedure described by Wan et al. [97]. Thus, $0.3 \mathrm{~g}$ of the plant sample was dry-ashed at $550{ }^{\circ} \mathrm{C}$ for $8 \mathrm{~h}$. Mo was then measured by the polarographic catalytic wave analysis method using a JP-4000 oscilloscope polarograph in a reaction solution $(2 \mathrm{~mL}$ $2.5 \mathrm{~mol} / \mathrm{L}$ sulfuric acid, $1 \mathrm{~mL} 0.5 \mathrm{~mol} / \mathrm{L}$ benzo hydroxy acetic acid, and $5 \mathrm{~mL}$ saturated sodium chlorate solution).

\subsection{Total RNA Extraction and Quantitative RT-PCR}

Frozen plant tissues were utilized for the total RNA extraction using TRIzol reagent (Invitrogen, Carlsbad, CA, USA). The quality and the concentration of the extracted RNA were assessed using 1.0\% agarose gel and NanoDrop 2000 spectrophotometer (Thermo Scientific, Waltham, MA, USA), respectively, thereafter, it was stored at $-70{ }^{\circ} \mathrm{C}$ until further use. Quantitative real-time PCR was carried out using an IQ5 Multicolor RT-PCR Detection System (Bio-Rad, Hercules, CA, USA) with SYBR Green Master (ROX) (Newbio Industry, China) according to the protocol provided by the manufacturer at a total reaction volume of $20 \mu \mathrm{L}$ [98]. The thermal cycling conditions were; $95^{\circ} \mathrm{C}$ for $3 \mathrm{~min}, 40$ cycles of amplification $\left(95{ }^{\circ} \mathrm{C}\right.$ for $10 \mathrm{~s}, 60$ or $58{ }^{\circ} \mathrm{C}$ for $30 \mathrm{~s}$, and $72{ }^{\circ} \mathrm{C}$ for $20 \mathrm{~s}$ ), and a final extension at $65{ }^{\circ} \mathrm{C}$ for $1 \mathrm{~min}$. Gene-specific primers for BnActin (as a reference gene) and for the other investigated genes (IRT1, HMA2, HMA3, HMA4, and PCS1) were designed using the primer designing tools of 
IDTdna (http: / / www.idtdna.com, access on 19 April 2018), as listed in Table S1. The gene expression was normalized using BnActin as a reference gene. The relative expression levels were calculated by comparing the cycle thresholds (CTs) of the target genes with that of the reference gene BnActin using the $2^{-\Delta \Delta C t}$ method $[99,100]$. The quantified data were analyzed using the Bio-Rad IQ 5 Multicolor Real-Time Manager software. Finally, the relative expression levels of different genes were detected. RT-PCR experiments were performed on three biological replicates, with three technical replicates for each sample.

\subsection{Statistical Analysis}

All the data were subjected to the two-way analysis of variance (ANOVA) using SPSS 22 software (SPSS inc., Chicago, IL, USA). Mean values of each treatment were compared using the Duncan test at the $p<0.05$ level. Figures display the mean and standard error of the data. Graphs were plotted using SigmaPlot 12.0 Software.

\section{Conclusions}

This study has identified foliar application of Mo and Se to affect their mutual absorption and accumulation in different plant tissues with a pronounced negative impact on B. napus growth in case of their combined application at the used dosages. Moreover, Mo and Se application could control Cd uptake, and its further accumulation in different parts, specially seeds, in the oilseed rape, with a minimum seed content of $\mathrm{Cd}$ in $\mathrm{Cd}+\mathrm{Mo}$ treatment. Foliar spraying of Se or Mo fertilizers seems to provide a protection role on pollen grains in B. napus when growing in Cd polluted soil. Furthermore, our results explain how Se and Mo could control Cd-content in seeds. While Se enhances the Cd-uptake in B. napus, it limits its accumulation in seeds via manipulating the expression level of PCS1 gene, which is responsible for phytochelatin production that drives Cd sequestration into plant cell vacuoles instead of having them interfere with cellular processes. On the other hand, Mo originally down-regulates the expression of IRT1 responsible for metal-uptake, and it further up-regulates $H M A 3$, mediating Cd efflux into leaves' vacuoles to finally control the accumulated $\mathrm{Cd}$ in seeds. Our study does not recommend the combined application of Se and Mo as foliar fertilizers for B. napus due to their negative effect on plant growth, even in non-polluted soil. However, further studies are still required to investigate the other possible techniques, such as seed soaking or seed additives, or the use of different doses of these fertilizers when applied as foliar spray.

Supplementary Materials: Supplementary materials can be found at http:/ /www.mdpi.com/1422-0067/19/8/ 2163/s1.

Author Contributions: M.A.I., C.X.H., and X.H.Z. designed the experiment; M.A.I. performed the experiment; M.A.I., A.M.E., Y.Y.Z., M.G.M., M.S.R., J.A., and M.I. analyzed the data; M.A.I. designed and wrote the manuscript; and C.X.H., X.H.Z., and A.M.E. revised it.

Funding: This research was funded by the National Natural Science Foundation of China, grant numbers 41571321 and 31201501 .

Acknowledgments: The authors are grateful for the support of the National Natural Science Foundation of China (41571321, 31201501). M.A.I. acknowledge Mohamed Ali, Usman Ali, and Cai Miaomiao for their continual help during the experimental work.

Conflicts of Interest: The authors declare no conflict of interest.

\section{References}

1. Gratão, P.L.; Polle, A.; Lea, P.J.; Azevedo, R.A. Making the life of heavy metal-stressed plants a little easier. Funct. Plant Biol. 2005, 32, 481-494. [CrossRef]

2. Biao, Z.J.; Nan, H.W. Advances on physiological and ecological effects of cadmium on plants. Acta Ecol. Sin. 2000, 20, 514-523.

3. Raskin, I.; Smith, R.D.; Salt, D.E. Phytoremediation of metals: Using plants to remove pollutants from the environment. Curr. Opin. Biotechnol. 1997, 8, 221-226. [CrossRef] 
4. Sanità di Toppi, L.; Gabbrielli, R. Response to cadmium in higher plants. Environ. Exp. Bot. 1999, 41, 105-130. [CrossRef]

5. Gill, S.S.; Tuteja, N. Reactive oxygen species and antioxidant machinery in abiotic stress tolerance in crop plants. Plant Physiol. Biochem. 2010, 48, 909-930. [CrossRef] [PubMed]

6. Selvam, A.; Wong, J.W.-C. Cadmium uptake potential of Brassica napus cocropped with Brassica parachinensis and Zea mays. J. Hazard. Mater. 2009, 167, 170-178. [CrossRef] [PubMed]

7. Ali, B.; Qian, P.; Jin, R.; Ali, S.; Khan, M.; Aziz, R.; Tian, T.; Zhou, W. Physiological and ultra-structural changes in Brassica napus seedlings induced by cadmium stress. Biol. Plant. 2014, 58, 131-138. [CrossRef]

8. Zhang, W.; Rengel, Z.; Kuo, J.; Yan, G. Aluminium effects on pollen germination and tube growth of Chamelaucium uncinatum. A comparison with other $\mathrm{Ca}^{2+}$ antagonists. Ann. Bot. 1999, 84, 559-564. [CrossRef]

9. Sawidis, T.; Reiss, H.-D. Effects of heavy metals on pollen tube growth and ultrastructure. Protoplasma 1995, 185, 113-122. [CrossRef]

10. Strickland, R.C.; Chaney, W.R. Cadmium influence on respiratory gas exchange of Pinus resinosa pollen. Physiol. Plant. 1979, 47, 129-133. [CrossRef]

11. Sabrine, H.; Afif, H.; Mohamed, B.; Hamadi, B.; Maria, H. Effects of cadmium and copper on pollen germination and fruit set in pea (Pisum sativum L.). Sci. Hortic. 2010, 125, 551-555. [CrossRef]

12. Holub, Z.; Ostrolucka, G. The effect of cadmium (II) and lead (II) on pollen germination and pollen tube growth in Quercus cerris, Pinus nigra and Picea abies. Biologia 1983, 38, 393-400.

13. Wang, X.; Gao, Y.; Feng, Y.; Li, X.; Wei, Q.; Sheng, X. Cadmium stress disrupts the endomembrane organelles and endocytosis during Picea wilsonii pollen germination and tube growth. PLoS ONE 2014, 9, e94721. [CrossRef] [PubMed]

14. Kumar, S.; Dhingra, H. Sexual reproduction and cadmium partitioning in two mungbean genotypes raised in soils contaminated with cadmium. Indian J. Plant Physiol. 2005, 10, 151.

15. Kaur, N.; Sharma, S.; Kaur, S.; Nayyar, H. Selenium in agriculture: A nutrient or contaminant for crops? Arch. Agronom. Soil Sci. 2014, 60, 1593-1624. [CrossRef]

16. Rayman, M.P. The importance of selenium to human health. Lancet 2000, 356, 233-241. [CrossRef]

17. Hasanuzzaman, M.; Hossain, M.A.; Fujita, M. Selenium in higher plants: Physiological role, antioxidant metabolism and abiotic stress tolerance. J. Plant Sci. 2010, 5, 354-375.

18. Feng, R.; Wei, C.; Tu, S. The roles of selenium in protecting plants against abiotic stresses. Environ. Exp. Bot. 2013, 87, 58-68. [CrossRef]

19. Filek, M.; Zembala, M.; Hartikainen, H.; Miszalski, Z.; Kornaś, A.; Wietecka-Posłuszny, R.; Walas, P. Changes in wheat plastid membrane properties induced by cadmium and selenium in presence/absence of 2, 4-dichlorophenoxyacetic acid. Plant Cell Tissue Organ Cult. 2009, 96, 19-28. [CrossRef]

20. Hristozkova, M.; Geneva, M.; Stancheva, I. Response of pea plants (Pisum sativum L.) to reduced supply with molybdenum and copper. Int. J. Agric. Biol. 2006, 8, 218-220.

21. Vieira, R.F.; Cardoso, E.J.B.N.; Vieira, C.; Cassini, S.T.A. Foliar application of molybdenum in common beans. I. Nitrogenase and reductase activities in a soil of high fertility. J. Plant Nutr. 1998, 21, 169-180. [CrossRef]

22. Agarwala, S.C.; Chatterjee, C.; Sharma, P.N.; Sharma, C.P.; Nautiyal, N. Pollen development in maize plants subjected to molybdenum deficiency. Can. J. Bot. 1979, 57, 1946-1950. [CrossRef]

23. Marschner, H. Marschner's Mineral Nutrition of Higher Plants, 3rd ed.; Academic press: Cambridge, MA, USA, 2011.

24. Gupta, U.C. Effect of methods of application and residual effect of molybdenum on the molybdenum concentration and yield of forages on podzol soils. Can. J. Soil Sci. 1979, 59, 183-189. [CrossRef]

25. Kaiser, B.N.; Gridley, K.L.; Ngaire Brady, J.; Phillips, T.; Tyerman, S.D. The role of molybdenum in agricultural plant production. Ann. Bot. 2005, 96, 745-754. [CrossRef] [PubMed]

26. Zhang, M.; Hu, C.; Zhao, X.; Tan, Q.; Sun, X.; Cao, A.; Cui, M.; Zhang, Y. Molybdenum improves antioxidant and osmotic-adjustment ability against salt stress in Chinese cabbage (Brassica Campestris L. Ssp. Pekinensis). Plant Soil 2012, 355, 375-383. [CrossRef]

27. Yamane, Y.; Fukuchi, M.; Li, C.; Koizumi, T. Protective effect of sodium molybdate against the acute toxicity of cadmium chloride. Toxicology 1990, 60, 235-243. [CrossRef] 
28. Hadi, F.; Ali, N.; Fuller, M.P. Molybdenum (Mo) increases endogenous phenolics, proline and photosynthetic pigments and the phytoremediation potential of the industrially important plant Ricinus communis L. for removal of cadmium from contaminated soil. Environ. Sci. Pollut. Res. 2016, 23, 20408-20430. [CrossRef] [PubMed]

29. Takahashi, R.; Bashir, K.; Ishimaru, Y.; Nishizawa, N.K.; Nakanishi, H. The role of heavy-metal ATPases, HMAs, in zinc and cadmium transport in rice. Plant Signal. Behav. 2012, 7, 1605-1607. [CrossRef] [PubMed]

30. Connolly, E.L.; Fett, J.P.; Guerinot, M.L. Expression of the IRT1 metal transporter is controlled by metals at the levels of transcript and protein accumulation. Plant Cell 2002, 14, 1347-1357. [CrossRef] [PubMed]

31. Hussain, D.; Haydon, M.J.; Wang, Y.; Wong, E.; Sherson, S.M.; Young, J.; Camakaris, J.; Harper, J.F.; Cobbett, C.S. P-type ATPase heavy metal transporters with roles in essential zinc homeostasis in Arabidopsis. Plant Cell 2004, 16, 1327-1339. [CrossRef] [PubMed]

32. Wong, C.K.E.; Cobbett, C.S. HMA P-type ATPases are the major mechanism for root-to-shoot Cd translocation in Arabidopsis thaliana. New Phytol. 2009, 181, 71-78. [CrossRef] [PubMed]

33. Chao, D.-Y.; Silva, A.; Baxter, I.; Huang, Y.S.; Nordborg, M.; Danku, J.; Lahner, B.; Yakubova, E.; Salt, D.E. Genome-wide association studies identify heavy metal ATPase3 as the primary determinant of natural variation in leaf cadmium in Arabidopsis thaliana. PLoS. Genet. 2012, 8, e1002923. [CrossRef] [PubMed]

34. Mendoza-Cózatl, D.G.; Jobe, T.O.; Hauser, F.; Schroeder, J.I. Long-distance transport, vacuolar sequestration, tolerance, and transcriptional responses induced by cadmium and arsenic. Curr. Opin. Plant Biol. 2011, 14, 554-562. [CrossRef] [PubMed]

35. Mendoza-Cózatl David, G.; Butko, E.; Springer, F.; Torpey Justin, W.; Komives Elizabeth, A.; Kehr, J.; Schroeder Julian, I. Identification of high levels of phytochelatins, glutathione and cadmium in the phloem sap of Brassica napus. A role for thiol-peptides in the long-distance transport of cadmium and the effect of cadmium on iron translocation. Plant J. 2008, 54, 249-259. [CrossRef] [PubMed]

36. Heslop-Harrison, P. Genetics, genomics and breeding of oilseed brassicas. Ann. Bot. 2013, 112. [CrossRef]

37. John, R.; Ahmad, P.; Gadgil, K.; Sharma, S. Heavy metal toxicity: Effect on plant growth, biochemical parameters and metal accumulation by Brassica juncea L. Int. J. Plant Prod. 2012, 3, 65-76.

38. El-Ramady, H.; Abdalla, N.; Taha, H.S.; Alshaal, T.; El-Henawy, A.; Salah, E.-D.F.; Shams, M.S.; Youssef, S.M.; Shalaby, T.; Bayoumi, Y. Selenium and nano-selenium in plant nutrition. Environ. Chem. Lett. 2016, 14, 123-147. [CrossRef]

39. Škarpa, P.; Kunzova, E.; Zukalova, H. Foliar fertilization with molybdenum in sunflower (Helianthus annuus L.). Plant Soil Environ. 2013, 59, 156-161. [CrossRef]

40. Steiner, F.; Zoz, T. Foliar application of molybdenum improves nitrogen uptake and yield of sunflower. Afr. J. Agr. Res. 2015, 10, 1923-1928.

41. Liu, H.; Hu, C.; Sun, X.; Tan, Q.; Nie, Z.; Su, J.; Liu, J.; Huang, H. Interactive effects of molybdenum and phosphorus fertilizers on grain yield and quality of Brassica napus. J. Food Agric. Environ. 2009, 7, 266-269.

42. Zhang, M.; Hu, C.; Sun, X.; Zhao, X.; Tan, Q.; Zhang, Y.; Li, N. Molybdenum affects photosynthesis and ionic homeostasis of Chinese cabbage under salinity stress. Commun. Soil Sci. Plant Anal. 2014, 45, 2660-2672. [CrossRef]

43. Wu, S.; Hu, C.; Tan, Q.; Xu, S.; Sun, X. Nitric oxide mediates molybdenum-induced antioxidant defense in wheat under drought stress. Front. Plant Sci. 2017, 8, 1085. [CrossRef] [PubMed]

44. Zhang, M.; Hu, C.; Zhao, X.; Tan, Q.; Sun, X.; Li, N. Impact of molybdenum on Chinese cabbage response to selenium in solution culture. Soil Sci. Plant Nutr. 2012, 58, 595-603. [CrossRef]

45. Hopper, J.L.; Parker, D.R. Plant availability of selenite and selenate as influenced by the competing ions phosphate and sulfate. Plant Soil 1999, 210, 199-207. [CrossRef]

46. Ramos, S.J.; Rutzke, M.A.; Hayes, R.J.; Faquin, V.; Guilherme, L.R.G.; Li, L. Selenium accumulation in lettuce germplasm. Planta 2011, 233, 649-660. [CrossRef] [PubMed]

47. Schiavon, M.; Pittarello, M.; Pilon-Smits, E.A.H.; Wirtz, M.; Hell, R.; Malagoli, M. Selenate and molybdate alter sulfate transport and assimilation in Brassica juncea L. Czern.: Implications for phytoremediation. Environ. Exp. Bot. 2012, 75, 41-51. [CrossRef]

48. DeTar, R.A.; Alford, É.R.; Pilon-Smits, E.A.H. Molybdenum accumulation, tolerance and molybdenum-selenium-sulfur interactions in astragalus selenium hyperaccumulator and nonaccumulator species. J. Plant Physiol. 2015, 183, 32-40. [CrossRef] [PubMed] 
49. Filek, M.; Keskinen, R.; Hartikainen, H.; Szarejko, I.; Janiak, A.; Miszalski, Z.; Golda, A. The protective role of selenium in rape seedlings subjected to cadmium stress. J. Plant Physiol. 2008, 165, 833-844. [CrossRef] [PubMed]

50. Saidi, I.; Chtourou, Y.; Djebali, W. Selenium alleviates cadmium toxicity by preventing oxidative stress in sunflower (Helianthus annuus) seedlings. J. Plant Physiol. 2014, 171, 85-91. [CrossRef] [PubMed]

51. Mroczek-Zdyrska, M.; Strubińska, J.; Hanaka, A. Selenium improves physiological parameters and alleviates oxidative stress in shoots of lead-exposed Vicia faba L. minor plants grown under phosphorus-deficient conditions. J. Plant Growth Regul. 2017, 36, 186-199. [CrossRef]

52. Wu, Z.; Yin, X.; Bañuelos, G.S.; Lin, Z.-Q.; Liu, Y.; Li, M.; Yuan, L. Indications of selenium protection against cadmium and lead toxicity in oilseed rape (Brassica napus L.). Front. Plant Sci. 2016, 7, 1875. [CrossRef] [PubMed]

53. Qing, X.; Zhao, X.; Hu, C.; Wang, P.; Zhang, Y.; Zhang, X.; Wang, P.; Shi, H.; Jia, F.; Qu, C. Selenium alleviates chromium toxicity by preventing oxidative stress in cabbage (Brassica campestris L. ssp. Pekinensis) leaves. Ecotoxicol. Environ. Saf. 2015, 114, 179-189. [CrossRef] [PubMed]

54. Gajewska, E.; Drobik, D.; Wielanek, M.; Sekulska-Nalewajko, J.; Gocławski, J.; Mazur, J.; Skłodowska, M. Alleviation of nickel toxicity in wheat (Triticum aestivum L.) seedlings by selenium supplementation. Biol. Lett. 2013, 50, 65-78. [CrossRef]

55. Wang, X.; Tam, N.F.-Y.; Fu, S.; Ametkhan, A.; Ouyang, Y.; Ye, Z. Selenium addition alters mercury uptake, bioavailability in the rhizosphere and root anatomy of rice (Oryza sativa). Ann. Bot. 2014, 114, 271-278. [CrossRef] [PubMed]

56. Chao, C.Y.; Ma, D.J. The Effects of Selenium on Toxicity of Copper on Rape. Adv. Mater. Res. 2013, 610-613, 288-291. [CrossRef]

57. Han, D.; Xiong, S.; Tu, S.; Liu, J.; Chen, C. Interactive effects of selenium and arsenic on growth, antioxidant system, arsenic and selenium species of Nicotiana tabacum L. Environ. Exp. Bot. 2015, 117, 12-19. [CrossRef]

58. Ding, Y.; Wang, R.; Guo, J.; Wu, F.; Xu, Y.; Feng, R. The effect of selenium on the subcellular distribution of antimony to regulate the toxicity of antimony in paddy rice. Environ. Sci. Pollut. Res. 2015, 22, 5111-5123. [CrossRef] [PubMed]

59. Landberg, T.; Greger, M. Influence of selenium on uptake and toxicity of copper and cadmium in pea (Pisum sativum) and wheat (Triticum aestivum). Physiol. Plant. 1994, 90, 637-644. [CrossRef]

60. Bluemlein, K.; Klimm, E.; Raab, A.; Feldmann, J. Selenite enhances arsenate toxicity in Thunbergia alata. Environ. Chem. 2009, 6, 486-494. [CrossRef]

61. Cartes, P.; Jara, A.A.; Pinilla, L.; Rosas, A.; Mora, M.L. Selenium improves the antioxidant ability against aluminium-induced oxidative stress in ryegrass roots. Ann. Appl. Biol. 2010, 156, 297-307. [CrossRef]

62. Fargasova, A.; Pastierová, J.; Svetková, K. Effect of Se-metal pair combinations (Cd, Zn, Cu, Pb) on photosynthetic pigments production and metal accumulation in Sinapis alba L. Seedlings. Plant Soil Environ. 2006, 52, 8-15. [CrossRef]

63. Zhang, M.; Hu, C.; Zhao, X.; Tan, Q.; Sun, X. Co-application of molybdenum and selenium fertilizers increase uptake, recovery and harvest index of molybdenum and selenium in pepper crop. J. Plant Nutr. 2016, 39, 244-251. [CrossRef]

64. Yousefi, N.; Chehregani, A.; Malayeri, B.; Lorestani, B.; Cheraghi, M. Investigating the effect of heavy metals on developmental stages of anther and pollen in Chenopodium botrys L. (Chenopodiaceae). Biol. Trace Elem. Res. 2011, 140, 368-376. [CrossRef] [PubMed]

65. Albooghobaish, N.; Zarinkamar, F. Effect of Lead Toxicity on Pollen grains in Matricaria chamomilla. In Proceedings of the International Conference on Bioscience, Biochemistry and Bioinformatics, Singapore, 26-28 February 2011; pp. 292-295.

66. Torabi, F.; Majd, A.; Enteshari, S.; Irian, S.; Nabiuni, M. Effects of salinity on the development of hydroponically grown borage (Borago officinalis L.) male gametophyte. Not. Bot. Horti Agrobot. Cluj Napoca 2013, 41, 8. [CrossRef]

67. Jiang, J.; Zhang, Z.; Cao, J. Pollen wall development: The associated enzymes and metabolic pathways. Plant Biol. 2013, 15, 249-263. [CrossRef] [PubMed]

68. Møller, I.M. A more general mechanism of cytoplasmic male fertility? Trends Plant Sci. 2001, 6, 560. [CrossRef] 
69. Tedeschini, E.; Proietti, P.; Timorato, V.; D'Amato, R.; Nasini, L.; Dei Buono, D.; Businelli, D.; Frenguelli, G. Selenium as stressor and antioxidant affects pollen performance in Olea europaea. Flora-Morphol. Distrib. Funct. Ecol. Plants 2015, 215, 16-22. [CrossRef]

70. Agarwala, S.; Sharma, C.; Farooq, S.; Chatterjee, C. Effect of molybdenum deficiency on the growth and metabolism of corn plants raised in sand culture. Can. J. Bot. 1978, 56, 1905-1908. [CrossRef]

71. Levent, T.A.; Bürün, B.; Yokaş, İ.; Coban, E. The effects of heavy metals on pollen germination and pollen tube length in the tobacco plant. Turk. J. Biol. 2002, 26, 109-113.

72. Xiong, Z.T.; Peng, Y.H. Response of pollen germination and tube growth to cadmium with special reference to low concentration exposure. Ecotoxicol. Environ. Saf. 2001, 48, 51-55. [CrossRef] [PubMed]

73. Sawidis, T. Effect of cadmium on pollen germination and tube growth in Lilium longiflorum and Nicotiana tabacum. Protoplasma 2008, 233, 95-106. [CrossRef] [PubMed]

74. Searcy, K.; Mulcahy, D. The parallel expression of metal tolerance in pollen and sporophytes of Silene dioica (L.) Clairv., S. alba (mill.) krause and Mimulus guttatus DC. Theor. Appl. Genet. 1985, 69, 597-602. [CrossRef] [PubMed]

75. De Flora, S.; Bennicelli, C.; Bagnasco, M. Genotoxicity of mercury compounds. A review. Mut. Res. Rev. Genet. Toxicol. 1994, 317, 57-79. [CrossRef]

76. Eshghi, S.; da Silva, J.A.T.; Ranjbar, R. Molybdenum and boron affect pollen germination of strawberry and fertile and infertile flowers of pomegranate. Fruit Veg. Cereal Sci. Biotechnol. 2010, 4, 148-150.

77. Raohavan, V.; Baruah, H. Effect of time factor on the stimulation of pollen germination and pollen tube growth by certain auxins, vitamins, and trace elements. Physiol. Plant. 1959, 12, 441-451. [CrossRef]

78. Bruyn, J.D. The in vitro germination of pollen of Setaria sphacelata. Physiol. Plant. 1966, 19, 365-376. [CrossRef]

79. Korshunova, Y.O.; Eide, D.; Clark, W.G.; Guerinot, M.L.; Pakrasi, H.B. The IRT1 protein from Arabidopsis thaliana is a metal transporter with a broad substrate range. Plant Mol. Biol. 1999, 40, 37-44. [CrossRef] [PubMed]

80. Rogers, E.E.; Eide, D.J.; Guerinot, M.L. Altered selectivity in an Arabidopsis metal transporter. Proc. Natl. Acad. Sci. USA 2000, 97, 12356-12360. [CrossRef] [PubMed]

81. Clemens, S.; Palmgren, M.G.; Krämer, U. A long way ahead: Understanding and engineering plant metal accumulation. Trends Plant Sci. 2002, 7, 309-315. [CrossRef]

82. Verret, F.; Gravot, A.; Auroy, P.; Leonhardt, N.; David, P.; Nussaume, L.; Vavasseur, A.; Richaud, P. Overexpression of AtHMA4 enhances root-to-shoot translocation of zinc and cadmium and plant metal tolerance. FEBS Lett. 2004, 576, 306-312. [CrossRef] [PubMed]

83. Mills, R.F.; Francini, A.; Ferreira Da Rocha, P.S.C.; Baccarini, P.J.; Aylett, M.; Krijger, G.C.; Williams, L.E. The plant $\mathrm{P}_{1 \mathrm{~B}}$-type ATPase AtHMA4 transports $\mathrm{Zn}$ and $\mathrm{Cd}$ and plays a role in detoxification of transition metals supplied at elevated levels. FEBS Lett. 2005, 579, 783-791. [CrossRef] [PubMed]

84. Wu, Z.; Zhao, X.; Sun, X.; Tan, Q.; Tang, Y.; Nie, Z.; Hu, C. Xylem transport and gene expression play decisive roles in cadmium accumulation in shoots of two oilseed rape cultivars (Brassica napus). Chemosphere 2015, 119, 1217-1223. [CrossRef] [PubMed]

85. Wong, C.K.E.; Jarvis, R.S.; Sherson, S.M.; Cobbett, C.S. Functional analysis of the heavy metal binding domains of the Zn/Cd-transporting ATPase, HMA2, in arabidopsis thaliana. New Phytol. 2009, 181, 79-88. [CrossRef] [PubMed]

86. Ueno, D.; Milner Matthew, J.; Yamaji, N.; Yokosho, K.; Koyama, E.; Clemencia Zambrano, M.; Kaskie, M.; Ebbs, S.; Kochian Leon, V.; Ma Jian, F. Elevated expression of TcHMA3 plays a key role in the extreme Cd tolerance in a Cd-hyperaccumulating ecotype of Thlaspi caerulescens. Plant J. 2011, 66, 852-862. [CrossRef] [PubMed]

87. Zhang, J.; Zhang, M.; Shohag, M.J.I.; Tian, S.; Song, H.; Feng, Y.; Yang, X. Enhanced expression of SaHMA3 plays critical roles in Cd hyperaccumulation and hypertolerance in Cd hyperaccumulator Sedum alfredii Hance. Planta 2016, 243, 577-589. [CrossRef] [PubMed]

88. Ueno, D.; Yamaji, N.; Kono, I.; Huang, C.F.; Ando, T.; Yano, M.; Ma, J.F. Gene limiting cadmium accumulation in rice. Proc. Natl. Acad. Sci. USA 2010, 107, 16500-16505. [CrossRef] [PubMed]

89. Sasaki, A.; Yamaji, N.; Ma, J.F. Overexpression of OsHMA3 enhances Cd tolerance and expression of Zn transporter genes in rice. J. Exp. Bot. 2014, 65, 6013-6021. [CrossRef] [PubMed] 
90. Hidenori, M.; Saki, A.; Aya, H.; Kouichi, T.; Nobushige, N.; Tomohiko, K.; Kazunao, K.; Ikuko, K.; Kenji, S.; Hidekazu, T.; et al. OsHMA3, a $\mathrm{P}_{1 \mathrm{~B}}$-type of ATPase affects root-to-shoot cadmium translocation in rice by mediating efflux into vacuoles. New Phytol. 2011, 189, 190-199.

91. Howden, R.; Goldsbrough, P.B.; Andersen, C.R.; Cobbett, C.S. Cadmium-sensitive, cad1 mutants of Arabidopsis thaliana are phytochelatin deficient. Plant Physiol. 1995, 107, 1059. [CrossRef] [PubMed]

92. Lillie, R.D. Histopathologic Technic and Practical Histochemistry, 3rd ed.; Blakiston Division: New York, NY, USA, 1965.

93. Chang, F.; Zhang, Z.; Jin, Y.; Ma, H. Cell biological analyses of anther morphogenesis and pollen viability in arabidopsis and rice. In Flower Development: Methods and Protocols; Riechmann, J.L., Wellmer, F., Eds.; Springer: New York, NY, USA, 2014; pp. 203-216.

94. Shivanna, K.R.; Sawhney, V.K. Polyethylene glycol improves the in vitro growth of brassica pollen tubes without loss in germination. J. Exp. Bot. 1995, 46, 1771-1774. [CrossRef]

95. Searcy, K.; Mulcahy, D. Comparison of the response to aluminum toxicity in gametophyte and sporophyte of four tomato (Lycopersicon esculentum Mill.) cultivars. Theor. Appl. Genet. 1990, 80, 289-295. [CrossRef] [PubMed]

96. Sakan, S.; Đorđević, D.; Dević, G.; Relić, D.; Anđelković, I.; Đuričić, J. A study of trace element contamination in river sediments in serbia using microwave-assisted aqua regia digestion and multivariate statistical analysis. Microchem. J. 2011, 99, 492-502. [CrossRef]

97. Wan, Y.H. Determination of soil available molybdenum and plant molybdenum by polarographic catalytic wave analysis. Chin. J. Soil Sci. 1988, 19, 43-46.

98. Li, P.; Dong, Q.; Ge, S.; He, X.; Verdier, J.; Li, D.; Zhao, J. Metabolic engineering of proanthocyanidin production by repressing the isoflavone pathways and redirecting anthocyanidin precursor flux in legume. Plant Biotechnol. J. 2016, 14, 1604-1618. [CrossRef] [PubMed]

99. Livak, K.J.; Schmittgen, T.D. Analysis of relative gene expression data using real-time quantitative pcr and the $2^{-\Delta \Delta C t}$ method. Methods 2001, 25, 402-408. [CrossRef] [PubMed]

100. Luo, H.; Zhu, Y.; Song, J.; Xu, L.; Sun, C.; Zhang, X.; Xu, Y.; He, L.; Sun, W.; Xu, H.; et al. Transcriptional data mining of Salvia miltiorrhiza in response to methyl jasmonate to examine the mechanism of bioactive compound biosynthesis and regulation. Physiol. Plant. 2014, 152, 241-255. [CrossRef] [PubMed]

(C) 2018 by the authors. Licensee MDPI, Basel, Switzerland. This article is an open access article distributed under the terms and conditions of the Creative Commons Attribution (CC BY) license (http:// creativecommons.org/licenses/by/4.0/). 